\title{
O proceso de depuración do maxisterio na provincia da Coruña
}

\section{The Purge of Schoolteachers in the Province of A Coruña}

\author{
Narciso DE GABRIEL \\ Universidade da Coruña
}

\begin{abstract}
RESUMO: Neste artigo ofrécese unha visión panorámica da depuración sufrida polo maxisterio público da provincia da Coruña entre 1936 e 1942, que conduciu á sanción dunha boa parte dos seus efectivos. Examínase primeiro a represión practicada polas autoridades militares e académicas, concentrada nos meses de agosto e setembro de 1936, e despois a realizada polo aparato especificamente depurador entre 1937 e 1942; diferénciase 0 alcance que tivo este proceso para mestras e mestres; descríbese a xeografía da represión, tomando o concello como unidade de análise; e revísanse os expedientes de depuración de Xosé Toba Fernández e de Palmira González López. As principais fontes utilizadas foron o Boletín Oficial do Estado e o Boletín Oficial da Provincia da Coruña, que permitiron cuantificar o proceso, e os expedientes de depuración, que resultan fundamentais para apreciar a súa dinámica e significado.
\end{abstract}

PALABRAS CHAVE: Franquismo; represión; depuración; maxisterio; A Coruña; Xosé Toba Fernández; Palmira González López.

ABSTRACT: This article offers an overview of the purge of public schoolteachers in the province of A Coruña from 1936 to 1942, which led to sanctions being imposed on a large part of these teachers. The article focuses first on the repression carried out by the military and academic authorities, concentrated in the months of August and September of 1936. It goes on to examine the repression conducted by the purge apparatus between 1937 and 1942 , differentiating the repercussions of this process on male and female schoolteachers. The geography of the repression is also described, using the municipality as the unit of analysis. The procedures against Xosé Toba Fernández and de Palmira González López during the purge are reviewed. The main sources used were the Official Gazette of the Central Government and the Official Gazette of the Province of A Coruña, which allowed us to quantify the process and the procedures -essential to gaining insight into the dynamics and meaning of the purge.

KEY WORDS: The Franco regime; repression; purge; schoolteachers; A Coruña; Xosé Toba Fernández, Palmira González 
Unha das primeiras medidas adoptadas polos que en xullo de 1936 crebaron a legalidade republicana foi a depuración das persoas que traballaban na Administración pública, por máis que tamén se promovese a de quen prestaba os seus servizos no sector privado. Entre os depurados salienta, polo seu volume, o profesorado, nomeadamente o maxisterio. As páxinas que seguen constitúen unha primeira versión da investigación que estou a realizar sobre este proceso na provincia da Coruña ${ }^{1}$. Non entraremos na análise da súa regulación, soportes institucionais, motivacións e significado -aínda que algunha observación se fará neste sentido-, que foron obxecto de numerosos estudos, aos que remitimos². O noso enfoque será, nesta nosa primeira achega, preferentemente cuantitativo nos tres primeiros apartados, mentres que nos dous últimos centraremos a atención nos expedientes de Xosé Toba Fernández e Palmira González López³.

Diferenciaremos dúas fases no proceso de depuración. Na primeira, o protagonismo correspondeu ás autoridades provinciais e rexionais, e máis concretamente á Delegación Militar de Instrución Pública e á Reitoría da Universidade de Santiago. Na segunda, o papel fiscalizador foi asumido polas comisións depuradoras provinciais, que remitían as súas propostas á Comisión de Cultura e Ensino da Xunta Técnica do Estado, substituída polo Ministerio de Educación Nacional a partir de xaneiro de 1938.

\section{Primeira fase}

Nos primeiros meses foron afastados do servizo 341 mestres e mestras que tiñan adxudicada unha escola pública, o que representaba o 19,33\% dos 1.764 que en xuño de 1936 cobraban a súa nómina con cargo aos orzamentos do Ministerio de Instrución Pública ${ }^{4}$. A porcentaxe ascendía ao $31,68 \%$ dos 846 mestres e descendía ata 0 7,95\% das 918 mestras.

\footnotetext{
${ }^{1}$ Existen algunhas publicacións de carácter local ou comarcal sobre proceso de depuración na provincia da Coruña, entre as que podemos citar a realizada por Xesús Costa Rodil e Xesús Santos Suárez, "De Padrón a Muros. A represión educativa e cultural, 1936-1950", Barbantía (2010): 53-101, e outras de ámbito galego, como é o caso da emprendida por Andrés Santalla López, "A depuración do Maxisterio e a educación pública en Galicia: 1936-1961", en A II República e a Guerra Civil (Actas do II Congreso da Memoria) (Narón: Asociación Cultural Memoria Histórica Democrática, 2005), 227-256. Antón Costa Rico tratou sobre este tema en sucesivas ocasións; véxase a súa Historia da educación e da cultura en Galicia (Vigo; Xerais, 2004), 1039-1061.

${ }^{2}$ A investigación de máis alcance seguramente segue a ser a publicada por Francisco Morente Valero hai xa dúas décadas: La escuela y el Estado Nuevo. La depuración del magisterio nacional (1936-1943) (Valladolid: Ámbito, 1997). Posteriormente realizáronse numerosas investigacións de ámbito local, comarcal, provincial, rexional e nacional. Véxase José Luís Hernández Huerta, "La represión franquista de la enseñanza. Fuentes y bibliografía (1975-2007) para el estudio de la depuración del magisterio nacional", Papeles Salmantinos de Educación, n.․11 (2008): 231-266, así como o artigo de Carmen Agulló que abre o presente monográfico de Sarmiento.

${ }^{3}$ Este traballo enmárcase nunha investigación de máis alcance iniciada en 2015, aproveitando 0 ano sabático que me foi concedido pola Universidade da Coruña.

${ }^{4} \mathrm{O}$ número total de mestres e mestras está extraído do libro de nóminas existente no Arquivo do Reino de Galicia (en adiante, ARG), Educación, Nóminas do mes de xuño de 1936. Sempre que foi posible identificalas, non se computaron as substitucións, para evitar contabilizar dúas veces unha mesma praza. Agradezo ao meu compañeiro e amigo José Luís Iglesias Salvado que me comunicase a existencia desta fonte, coa que leva traballando varios anos. A cifra coa que aquí traballamos está moi próxima aos 1.736 integrantes do maxisterio coruñés rexistrados pola Sección administrativa de ensino primario da provincia da Coruña en escrito dirixido
} 
A sanción máis recorrente foi a suspensión de emprego e soldo, seguida da destitución. A primeira medida tiña carácter provisorio, como advertía a Delegación Militar de Instrución Pública, mentres que a segunda era indefinida e, en principio, definitiva ${ }^{5}$. En todo caso, a duración da suspensión só comezou a se concretar a partir da listaxe publicada 028 de agosto. Polo demais, entre unha e outra categoría houbo transvasamentos: seis dos inicialmente destituídos foron suspendidos posteriormente, ao tempo que 28 viron endurecida a sanción. Considerando unicamente a decisión final de cada sancionado nesta primeira fase, a destitución afectou aproximadamente ao $46 \%$ dos sancionados e a suspensión ao 54\%. Como se pode apreciar na Táboa 1, a primeira predominaba lixeiramente entre os homes e a segunda amplamente entre as mulleres ${ }^{6}$. Só un dos sancionados, Xosé Toba Fernández, foi castigado coa excedencia forzosa con dereito a dous terzos do soldo (Boletín Oficial da Provincia da Coruña, en adiante BOP, 19/9/1936) .

Os cómputos realizáronse a partir das listaxes de sancións publicadas no Boletín Oficial da Provincia da Coruña durante os meses de agosto -concentra case o 69\% dos rexistros (235)-, setembro (100) e outubro, novembro e decembro (unha por mes) de 1936, ás que se suman tres en 1937. Contabilízase o número de sancionados, e non o de sancións, que é superior, pois nalgúns casos estas amplíanse ou redúcense e mesmo se reiteran, ás veces no mesmo número do BOP. Só se tomaron en consideración as sancións que se fixeron públicas de forma oficial. A pescuda noutro tipo de fontes posiblemente faría agromar algunha outra, mais o seu número seguramente sería pouco significativo ${ }^{8}$, entre

ao reitor o 24 de setembro de 1936 (Arquivo Histórico Universitario de Santiago -en adiante AHUS-, Ensino Primario, Caixa 178).

${ }^{5}$ Comunicación dirixida pola Delegación á Sección administrativa de ensino primario, 19/8/1936, ARG, Educación, caixa 4216.

${ }^{6}$ Entre os suspensos, inclúense os inhabilitados para exercer o ensino durante un determinado período de tempo -polo regular eran interinos-, e entre os destiuídos, un separado definitivamente, César Boedo Feal, mestre de Baltar (Curtis) (BOP, 27/9/1937).

${ }^{7}$ En escrito dirixido ao xefe da Sección administrativa de ensino primario (25/8/1936), o delegado militar especificaba que tamén quedaba privado da gratificación como axudante de Pedagoxía na Escola Normal de Santiago (ARG, Educación, caixa 4216).

${ }^{8}$ No libro de rexistro "Movimiento del personal, 1934-1940", conservado no ARG (Educación, libro 34.996), aparece algunha que outra sanción non publicada oficialmente. Sirva como exemplo Enrique Pérez Vionde, mestre de Cacheiras (Teo), de quen se di que foi destituído o 11 de xaneiro de 1937. A revisión da documentación da Delegación Militar e da Reitoría neste mesmo Arquivo (Educación, caixa 4216) só permitiu identificar dúas sancións non localizadas previamente no BOP. Unha é a de Adela Panisse Ferrer, mestra interina da escola mixta de Vigo de Abaixo, que cesou no cargo o 9 de setembro de 1936 por orde da Delegación Militar (supoñemos que sancionada), segundo consta en oficio do delegado civil do concello de Paderne. No libro de rexistro antes mencionado especifícase a súa condición de alumna-mestra, e tamén se deixa constancia de que foi reposta no cargo aos poucos meses. Será habilitada para exercer o ensino na segunda fase do proceso de depuración (BOP, 6/3/1942). O segundo caso é o de Anacleto Casás Villanueva, suspendido de emprego e soldo por tres meses polo gobernador civil de Ourense; así o comunica o 29 de agosto de 1936 a sección administrativa desta provincia ao delegado civil de Neda, onde exercía o mestre, e o delegado deste concello á Delegación Militar da Coruña. Tamén existen catro oficios da Reitoría en virtude dos cales se prolongaba a suspensión de emprego e soldo de Elvira González Losada (Mera-Ortigueira), José Canle Franco (Vigo de Abaixo-Paderne), Josefa Gómez Regueiro (Outeiro-Ames) e Gumersinda Sanz Martínez (Melide) mentres non se resolvían definitivamente os expedientes de depuración; estas ampliacións temporais non se recollen na listaxe publicada no BOP (1/4/1937). 
outras razóns porque a publicidade formaba parte do mecanismo represor do proceso de depuración, aplicado tanto con intención punitiva como disuasoria.

Táboa 1. Sancionados/as a proposta da Delegación Militar e da Reitoría (1936-1937)

\begin{tabular}{|l|c|c|c|}
\hline & Mestres & Mestras & Total \\
\hline Destitución & 111 & 18 & 129 \\
\hline Suspensión & 128 & 49 & 177 \\
\hline Destitución e posterior suspensión & 2 & 4 & 6 \\
\hline Suspensión e posterior destitución & 26 & 2 & 28 \\
\hline Excedencia forzosa & 1 & 0 & 1 \\
\hline Total & 268 & 73 & 341 \\
\hline Porcentaxe sobre o total do maxisterio & 31,68 & 7,95 & 19,33 \\
\hline & Porcentaxe sobre o total das sancións \\
\hline Destitución & 51,31 & 27,40 & 46,18 \\
\hline Suspensión & 48,69 & 72,60 & 53,82 \\
\hline
\end{tabular}

Fonte: Elaboración propia a partir do BOP da Coruña

Semella, no entanto, que algunhas sancións iniciais non foron rexistradas nas páxinas do BOP. Entre os mestres aos que se lles recoñeceu en 1937 o dereito a retornaren á escola mentres non se resolvía o expediente, aparece algún cuxa sanción descoñecemos ${ }^{9}$, e o mesmo sucede entre os suspensos de emprego e soldo aos que se lles concedeu en 1940 o dereito a percibiren a metade do salario ${ }^{10}$. Pola súa banda, os que na segunda fase foron confirmados no cargo polo Ministerio con perda dos haberes deixados de percibir, ou repostos con dereito a percibilos, tiveron que ser sancionados nalgún momento, por máis que en ocasións descoñezamos a natureza da sanción ${ }^{11}$. Ningún destes casos está incluído nos 341 que aparecen na Táboa 1, por descoñecermos a sanción recibida, a data e a instancia que a promoveu, malia o estaren na Táboa 3, que dá conta dos resultados da segunda fase.

\footnotetext{
${ }^{9}$ Trátase de Manuel Bermúdez de Castro (Ortigueira) e Francisco Veiga García (Teo) (BOP, 17/12/1938).

${ }^{10}$ Ademais dos dous anteriores, aparecen na listaxe os nomes de Arístides Fermoso Miranda (Serantes), Antonio Martínez González (Neda) e Román Moreno Palomares (Ortigueira) (BOP, 30/1/1940).

${ }^{11}$ Entre os primeiros áchanse Belisario Rodríguez Caneiro (Oleiros) e Clotilde Stolle Liñares (Padrón), e entre os segundos, Jesús Iglesias Fernández (Touro). Segundo o libro de rexistro xa citado (ARG, "Movimiento del personal, 1934-1940"), a este último foille anulada a sanción polo reitor o 2 de decembro de 1936.
} 
A estas sancións habería que engadir as que recaeron sobre o profesorado que estaba en excedencia, como Luís Barreiro Paradela ${ }^{12}$ e posiblemente Jesús Mejuto Vázquez ${ }^{13}$, ou aquel que dependía doutros ministerios, caso de Elvira Bao, quen exercía como mestra nas colonias escolares do Sanatorio Marítimo de Oza ${ }^{14}$, e mais Arsenio Cristóbal de la Fuente, que traballaba no cárcere da Coruña ${ }^{15}$. E desde logo aquel que estaba empregado no sector privado, e concretamente nas escolas de fundación, así como os normalistas -alumnado das escolas de maxisterio que estaba a cursar o Plan Profesional- e os cursillistas -mestres e mestras que realizaran os cursiños de selección, implantados pola República en substitución das tradicionais oposicións ${ }^{16}$.

Os golpistas decretan o 12 de agosto os primeiros castigos, que se distribúen en tres ordes. En virtude da primeira, referida ao Consello Provincial de Ensino Primario, destitúese 0 seu presidente, Arturo Taracido ${ }^{17}$, as vogais Elvira Bao ${ }^{18}$ e María Barbeito ${ }^{19}$-as dúas mestras xa mencionadas- e os tamén vogais e inspectores Vicente Moltó e Gabriel Loperena. A segunda recolle a suspensión de emprego e soldo dun inspector (Gabriel Loperena), catro mestres e dúas mestras. A terceira refírese exclusivamente ao maxisterio, e concrétase en 13 homes e tres mulleres (BOP, 13/8/1936). As dúas persoas que cerraban esta última listaxe eran María Vázquez Suárez (Miño) ${ }^{20}$ e Mercedes Romero Abella ( $A$ Coruña $)^{21}$, que foron asasinadas algunhas semanas máis tarde $e^{22}$.

\footnotetext{
${ }^{12}$ Separación definitiva (BOP, 27/3/1942).

${ }^{13}$ Foi destituído polas autoridades militares como inspector das escolas do Hospicio Municipal da Coruña (BOP, 21/8/1936) e posteriormente separado da profesión polo Ministerio (BOP, 8/7/1940). Sobre a súa biografía pode consultarse Carlos Pereira Martínez, Miradoiro da Ría, CNT-A Coruña, novembro 2009 (http://www.cntgaliza.org/ files/MiradoiroDaRia.pdf).

${ }^{14}$ No BOP do 24 de agosto noméase a María Dolores García Calviño para a vacante existente en Oza por mor da "destitución" de Elvira Bao Maceiras, e no do 13 de agosto publícase a destitución de Emilia Chao, profesora permanente de nenas no Sanatorio de Oza. Ben podería ser unha confusión e tratarse da propia Elvira Bao. De feito, esta recibiu un escrito do gobernador civil datado 031 de agosto informándoa que quedaba afastada do ensino desde 013 dese mesmo mes. Cfr. Sabela Rivas Barrós, A derradeira lección dos mestres (Vigo: Xerais, 2001), 220. ${ }^{15}$ Suspendido de emprego e soldo (BOP, 28/8/1936).

${ }^{16} \mathrm{O}$ gobernador civil da Coruña declaraba que mesmo era necesario revisar os estatutos e regulamentos das escolas creadas polos americanos para detectar a presenza de "contenidos nocivos a las normas del Nuevo Estado y a los sagrados intereses de la enseñanza" (BOP, 3/1/1941).

${ }^{17}$ Posteriormente foi declarado polo reitor destituído e cesante na Escola de Comercio coruñesa (BOP, 15/9/1936). Será perseguido como masón, e entre os cargos que se lle apuñan salientaba a súa condición de presidente da Asociación de Pais de Familia para a Defensa do Laicismo no Ensino. Cfr. María del Pilar Mera Costas, "Perseguindo traidores. A represión da masonaría en Galiza (1936-1939)", en Emilio Grandío (ed.), Vixiados. Represión, investigación e vixilancia na Galiza da Guerra Civil (1936-1939) (Ames: Laiovento, 2011), 205-254.

${ }^{18}$ Rivas Barrós, A derradeira lección dos mestres, 211-224.

${ }^{19}$ Ana Romero Masiá, María Barbeito. Unha vida ao servizo da escola e dos escolares (1880-1970) (A Coruña: Baía Edicións, 2014).

${ }^{20}$ Luís Lamela, "O paseo de Mercedes Romero Abella", Unión Libre. Cadernos de vida e culturas, n.․11 (2006): 63-72.

${ }^{21}$ Juan Sobrino Ceballos e Manuel Domínguez Ferro, "'iQue pouco vale unha mestra' Un achegamento á figura de María Vázquez Suárez", Cátedra. Revista eumesa de estudios, no․ 18 (2011): 209-227.

${ }^{22}$ Sobre a depuración do maxisterio coruñés asasinado, executado ou morto por mor da sublevación, pode consultarse un traballo da miña autoría titulado "Os mestres mortos daquel verán", cuxa publicación está prevista no número 108 d'A Trabe de Ouro.
} 


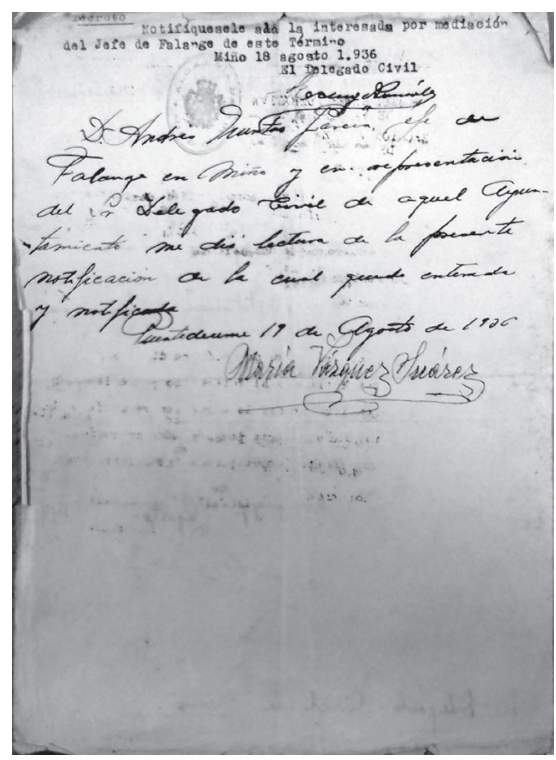

1.1. O delegado civil de Miño comunicou a María Vázquez Suárez a súa destitución por medio do xefe local da Falanxe. Era o 19 de agosto de 1936. A mestra será asasinada na madrugada dese mesmo día (ARG, Educación, caixa 4216).

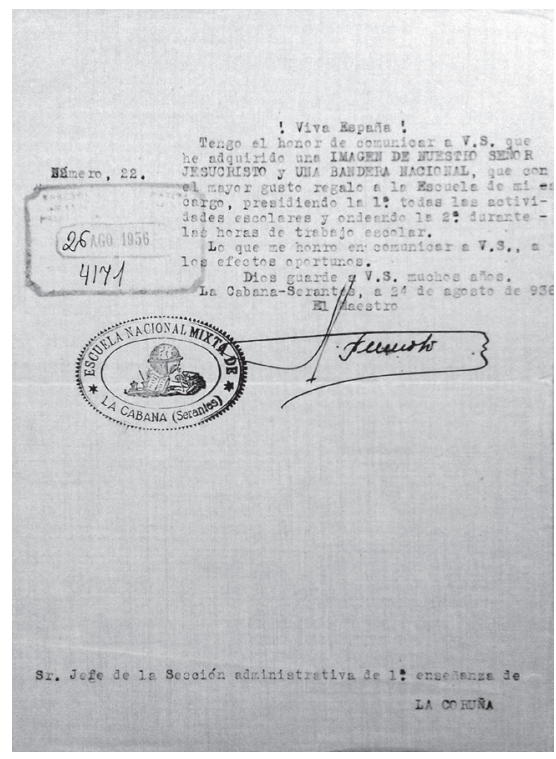

1.2. O nacional-catolicismo terá no crucifixo e na bandeira dous dos seus símbolos máis senlleiros. Arístides Fermoso Miranda, necesitado de facer méritos, agasallará a súa escola con ambos (ARG, Educación, caixa 4216)

Ata 05 de setembro as ordes estaban asinadas polo gobernador civil, Florentino González Vallés, e foran adoptadas a proposta de Jesús Quiroga, marqués da Atalaya, nomeado delegado militar de Instrución Pública. 09 e 015 de setembro as medidas adoptáronse a proposta do reitor e levaban a sinatura de Jesús Quiroga, que actuaba por delegación: "Por el Rector de la Universidad, el Delegado militar". As ordes de outubro, novembro e decembro de 1936 e as de 1937 tamén tiñan a súa orixe no reitor ${ }^{23}$.

A Delegación Militar actuou con présa e sen a necesaria ponderación dos escasos datos de que dispuña. Así se pon de manifesto na rapidez con que se adoptaron as decisións, as repeticións de nomes nas listaxes -nalgún caso, un mestre aparece como destituído e suspendido no mesmo $\mathrm{BOP}^{24}$-, os erros ao identificar correctamente os mestres e as escolas en que exercían, o carácter dicotómico das sancións ou a falta de concreción inicial da duración das suspensións de emprego e soldo. Polo demais, os sancionados en toda a primeira fase non tiveron posibilidade de defenderse antes de se ditaren as resolucións co-

\footnotetext{
${ }^{23}$ A actuación da Universidade de Santiago no proceso de depuración foi analizada por Ricardo Gurriarán en Ciencia e conciencia na Universidade de Santiago (1900-1940) (Santiago: Universidade de Santiago de Compostela, 2006).

${ }^{24}$ Carlos Luís Gómez Gómez (Cee) (BOP, 19/8/1936).
} 
rrespondentes, aínda que moitos deles se dirixiron, con moi escaso éxito, ás autoridades militares ou académicas para solicitar clemencia ${ }^{25}$. A única sanción cuxa anulación fixeron pública os militares foi a de Felipe Carnicer López, mestre da escola de Silva de Abaixo na cidade da Coruña (BOP, 21/8/1936) ${ }^{26}$.

Comparadas coas adoptadas pola autoridade militar, as sancións acordadas pola Reitoría foron menos numerosas -276 fronte a 65 - e tiveron un carácter máis colexiado, dado que o reitor (Pedro Pena Pérez, primeiro, e Felipe Gil Casares máis adiante) contaba co asesoramento da Xunta de Decanos. Tamén foron algo máis matizadas, pois nesta instancia introdúcese unha nova modalidade de sanción, o traslado, que de momento non é autónoma, senón que está asociada á suspensión de emprego e soldo, e especifícase a duración deste último castigo, que ascendía polo regular a un ano -era o máis usual-, seis meses ou tres meses. Finalmente, se os militares optaron pola destitución en case $045 \%$ das sancións, os académicos fixérono en aproximadamente o 17\%. Foron, xa que logo, menos contundentes, circunstancia á que posiblemente contribuíu o feito de que xa estaba castigado o sector do maxisterio considerado máis perigoso polos sublevados.

Táboa 2. Sancionados/as pola Reitoría (1936-1937)

\begin{tabular}{|l|c|c|c|c|c|c|}
\hline & Mestres & Mestras & Total & Mestres (\%) & Mestras (\%) & Total (\%) \\
\hline Destitución & 9 & 2 & 11 & 18,75 & 11,76 & 16,92 \\
\hline Suspensión & 34 & 11 & 45 & 70,83 & 64,71 & 69,23 \\
\hline Suspensión e traslado & 4 & 4 & 8 & 8,33 & 23,53 & 12,31 \\
\hline Separación definitiva & 1 & 0 & 1 & 2,08 & 0,00 & 1,54 \\
\hline Total & 48 & 17 & 65 & & & \\
\hline
\end{tabular}

Fonte: Elaboración propia a partir do BOP da Coruña

O reitor revisou algunhas sancións da Delegación Militar, quer para amplialas ou reducilas, quer para concretar a duración da suspensión, isto último en termos similares aos que acabamos de aludir. Este tipo de actuacións non se rexistra na táboas 1 e 2, que só se refiren á primeira sanción de que foi obxecto cada unha das mestras e dos mestres.

\footnotetext{
${ }^{25}$ Antes de se crear a Comisión depuradora provincial, a Reitoría, auxiliada pola Inspección de ensino primario, e recorrendo basicamente a datos fornecidos polos militares, iniciou o proceso de depuración, remitindo aos mestres e mestras xa sancionados os cargos que se lles apuñan, para que estes contestasen o que estimasen oportuno. Este proceso interrompeuse a finais de 1936, e a documentación por el xerada foi entregada ao organismo depurador.

${ }^{26}$ A Delegación Militar tamén propuxo a anulación ou redución dalgunhas outras sancións ao reitor, que este publicou no BOP (AHUS, Ensino Primario, Caixa 178). Unha das propostas referíase a Serafín de Haro Coello (Santiago-O Avío), quen ao solicitar a revisión do seu expediente -na segunda fase fora separado do ensino-, alegaba "haber sido quizá el único depurado en la provincia por el Excmo Sr Delegado Militar de manera que me honra [a sanción fora anulada], por quedar patente mi honorabilidad" (AGA, 32/12523-2).
} 
Tanto a instancia militar como a civil baseaban as súas decisións nos informes que lles remitían as novas autoridades locais, así como a Garda Civil, a policía, o clero e confidentes varios. Jesús Quiroga, delegado militar de Instrución Pública, asina 07 de agosto unha orde dirixida aos "subdelegados militares" da provincia para que remitan un informe sobre os mestres nacionais de ensino primario da súa demarcación, "con arreglo a las instrucciones que recibirán de dicha Delegación", que estaba localizada na praza de Galicia, número 22 (BOP, 11/8/1936). Esta orde marca o inicio da primeira fase do proceso de depuración ${ }^{27}$.

Uns días máis tarde (BOP, 26/8/1936), o gobernador civil, Florentino González Vallés, dá instrucións para cubrir as vacantes ocasionadas polas primeiras disposicións depuradoras -a súa provisión sería decidida polo propio Goberno civil a instancia da Delegación militar-, que xustifica nos seguintes termos:

Las perniciosas doctrinas e ideas disolventes que han sido propaladas de una manera solapada 0 pública por los antipatriotas que conducian a nuestra querida España a su desaparición como Nación civilizada, tenían desgraciadamente un campo de experimentación señaladísimo en los centros docentes y muy especialmente en las Escuelas Nacionales de Primera Enseñanza, donde, deformando las tiernas inteligencias infantiles, creaban generaciones inspiradas únicamente en un espíritu de odio y carentes en absoluto de ideas de cristiandad y patriotismo.

Una parte de nuestro Magisterio, unas veces inconsciente del gran daño que ocasionaba, y otras sabedora de su labor destructiva y anárquica, encontró especialmente como terreno abonado para propagar sus descabelladas doctrinas, aquellos lugares que la poca ilustración hacía propicios para envenenar el corazón del pobre campesino, a quien se le prometía con aquellas predicaciones un edén, cuando en realidad se le conducía a su definitiva perdición y aniquilamiento, como si no consideraran suficiente inculcar a inocentes niños ideas inconcebibles de odio y perversión, e inspirarles el mayor desprecio hacia lo más sagrado que, como cristianos y españoles, aprendieron de nuestros antepasados.

Esto hace resaltar grandemente la gran labor patriótica y cristiana que, en medio de esta ola que nos envolvía, mantuvo con energía y decisión un gran plantel del Profesorado, que supo sustraerse a la coacción moral, y aun en muchos casos material, que sobre ellos se ejercía.

Por estas razones fue imprescindible y necesario efectuar una labor de depuración, sancionando enérgicamente a muchos Catedráticos, Profesores y Maestros, y llegando, incluso, a eliminar de sus funciones a los que loca o perversamente eran nocivos para la enseñanza.

Eliminándoos das súas funcións e ás veces tamén deste mundo, como así se fixo con, cando menos, dúas das mestras e 25 dos mestres sancionados.

\section{Segunda fase}

A segunda fase iníciase coa creación das comisións depuradoras do profesorado (Decreto do 8 de novembro de 1936), que no caso do maxisterio tiñan carácter provincial. Estas comisións solicitaban informes do alcalde, o cura párroco, o comandante do posto da Garda Civil e un pai de familia, aos que se podían unir outros, de se estimaren necesarios; nalgunha ocasión os seus membros mesmo se desprazaban ao lugar onde exercía o mestre ou a mestra para recoller información in situ. En función dos informes recibidos, redac-

\footnotetext{
${ }^{27}$ Unha descrición dos inicios deste proceso no concello de Lousame pode lerse en Xerardo Agrafoxo, Memoria do Franquismo. A época do wólfram en Lousame. A corporación de Noia en Meirás (Noia: Toxosoutos, 2002), 241-277.
} 
tábase o prego de cargos, aos que o imputado debía contestar no prazo de dez días, alegando na súa defensa as probas que considerase oportunas. Seguidamente, facíase unha proposta de resolución, normalmente por unanimidade, que se trasladaba ás autoridades superiores. Para a tramitación destas propostas, que se contaban por milleiros, creáronse a nivel central organismos específicos: a Oficina Técnico-Administrativa (Orde do 11 de marzo de 1938), a Comisión Superior Ditaminadora dos Expedientes de Depuración (Orde do 18 de marzo de 1939) e o Xulgado Superior de Revisións (Orde do 30 de xaneiro de 1942). A resolución final correspondía á Comisión de Cultura e Ensino da Xunta Técnica do Estado ata xaneiro de 1938 e ao Ministerio de Educación Nacional a partir desa data.

A Comisión provincial da Coruña constituíuse 01 de decembro de 1936 ${ }^{28}$, e unha das súas primeiras actuacións públicas consistiu en requirir a Rodrigo Álvarez Gantes (Boiro-Escarabote), a través do BOP (3/2/1937), para que comunicase o domicilio ao que debía ser remitido o prego de cargos. Co propósito de recoller información dos chamados a fornecela, elaborou un cuestionario que facía referencia á conduta profesional, social e particular, e sobre todo ás actividades políticas e sociais dos depurados; estas últimas nomeadamente a relación coa Fronte Popular- resultarán determinantes para formular as propostas de sanción e posteriores ordes resolutorias.

O cuestionario enviouse ao prelo en decembro de 1936 asinado por Ángel Díaz Grande, catedrático de Matemáticas e director do Instituto da Coruña. A súa participación na Comisión debeu ser moi breve, pois as cinco persoas que realizaron a maior parte das propostas foron Enrique Montenegro López, catedrático de Xeografía e Historia e director do instituto de Ferrol, quen xa asina as actas como presidente desde os primeiros días de febreiro de 193729; Antonio Eiján, inspector xefe de ensino primario, a quen se alude como vicepresidente; Ramón Lamela Cernadas, mestre nas escolas do Hospicio coruñés, que actuou como secretario, e polo que intúo debeu desempeñar un papel particularmente relevante; José Martínez Pereiro, mestre e avogado, que tivo diversos cargos e empregos, entre eles os de letrado do Concello da Coruña ${ }^{30}$ e director de El Ideal Gallego; e, finalmente, Antonio Chaos Losada, médico de Ferrol.

Montenegro e Chaos, os dous membros ferroláns, faltaban a miúdo ás reunións por careceren de medios para se desprazar ata a cidade herculina. En 1939 deixan de formar parte do organismo depurador e son substituídos por Antonio Bermejo de la Rica, catedrático de Xeografía e Historia do Instituto da Coruña, e Eugenio Vázquez Gundín, rexistrador da propiedade e deputado pola Confederación Española de Dereitas Autónomas (CEDA) en 1933. Parece que Bermejo de la Rica foi substituído, á súa vez, por José Sánchez

\footnotetext{
${ }^{28}$ Comunicación da Delegación Militar de Instrución Pública ao reitor, 3 de decembro de 1936, AHUS, Ensino Primario, Caixa 178.

${ }^{29}$ Ao igual que Díaz Grande, foi depurado e confirmado no cargo en 1941. Cfr. Olegario Negrín Fajardo, "La depuración franquista del profesorado en los institutos de segunda enseñanza en España (1937-1943). Estudio cuantitativo para Galicia", Sarmiento. Anuario Galego de Historia da Educación, n.. 10 (2006): 59-99.

${ }^{30}$ Foi separado deste cargo en 1932, acusado polo concello coruñés de dirixir "una campaña de desprestigio de la República". Véxase Emilio Grandío Seoane, A Segunda República en Galicia. Memoria, mito e historia (Vigo: Nigratrea, 2010), 99.
} 


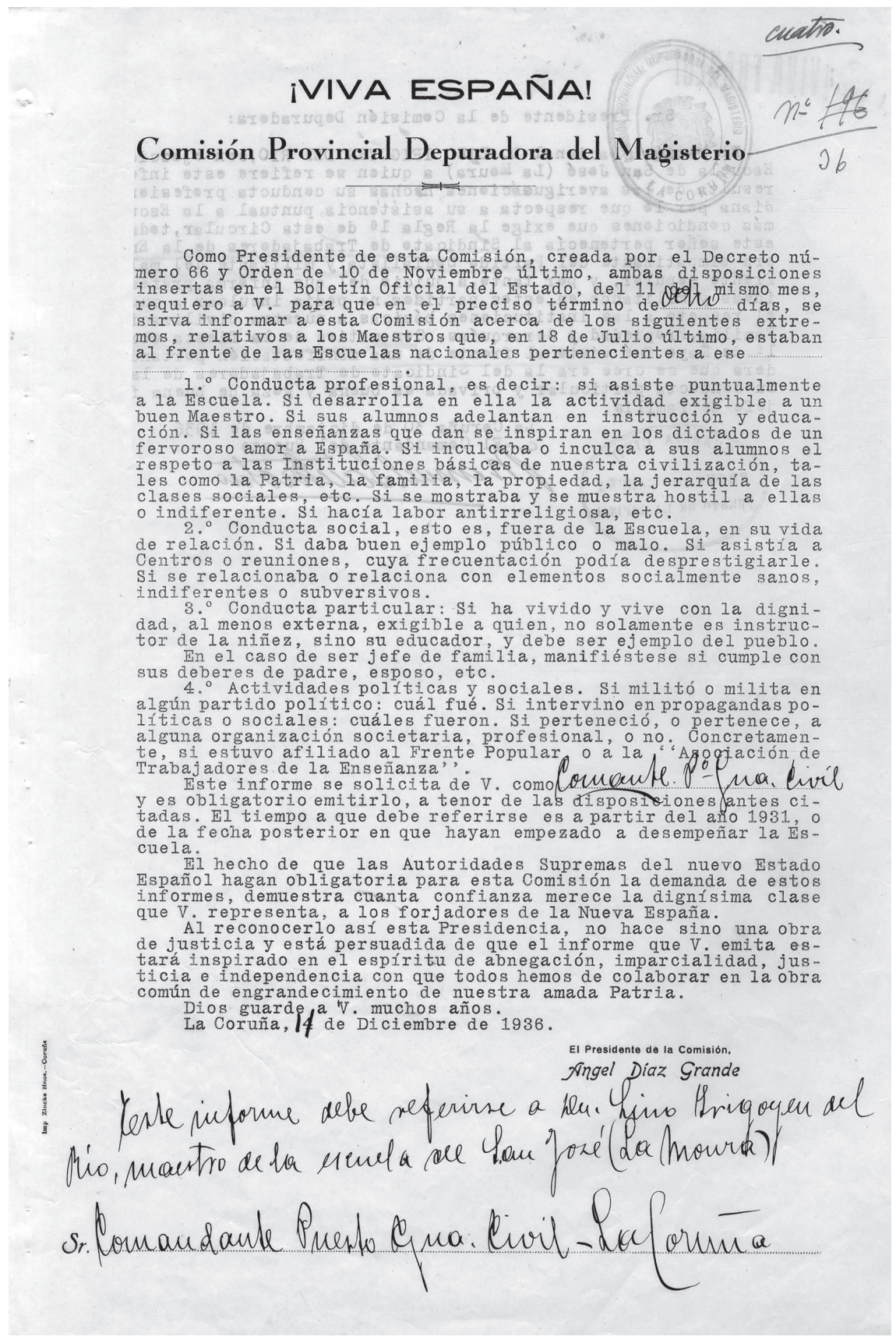

2. Primeiro cuestionario elaborado pola Comisión depuradora da Coruña para recadar información sobre a conduta do maxisterio (AGA, 32/13180-14). 
Mosquera, nome que seguramente corresponde ao profesor de Relixión do Instituto coruñés por esas datas ${ }^{31}$.

Na Táboa 3 rexístrase o resultado da segunda fase do proceso de depuración de 506 mestres e mestras, $067 \%$ dos cales xa foran sancionados inicialmente. A primeira resolución fíxose pública no BOE o 14 de maio de 1937 e a última no BOP o 22 de decembro de $1942^{32}$, se exceptuamos o caso de José María Pita Cendán ${ }^{33}$. Inclúense os sancionados na fase final, pero tamén os que o foron na primeira ${ }^{34}$, e prescíndese daqueles que non recibiron ningún tipo de sanción en ningunha das dúas fases.

A confirmación no cargo era unha resolución única, e tamén o eran, ou podían selo, determinadas sancións (separación definitiva do ensino, reposición con perda dos haberes deixados de percibir, reposición con dereito a haberes e sanción moral que supuxo a publicidade do castigo decretado nun primeiro momento), polo que o seu o número coincide co de sancionados, pero outras incluían máis dunha medida. Neste caso computamos a potencialmente máis severa, con base na seguinte orde descendente, que coincide coa que adoitaban seguir as ordes ministeriais na súa enumeración: suspensión de emprego e soldo, traslado e inhabilitación para desempeñar cargos directivos e de confianza ${ }^{35}$. Desta forma, centramos a atención nos sancionados, que constitúen o noso principal foco de interese, e asemade simplificamos, neste primeiro cadro, a presentación dos datos.

A sanción máis común foi a separación definitiva do ensino e a baixa na escala do maxisterio, que afectou a case $010 \%$ dos seus efectivos e representou unha de cada tres decisións adoptadas polas autoridades centrais ${ }^{36}$. Algún, como Xosé Toba Fernández, foi separado en dúas ocasións, primeiro como auxiliar de Pedagoxía na Escola Normal de Santiago (BOE, 14/5/1937) e logo como mestre na anexa desta institución (BOP, 11/5/1940), aínda que nos nosos cómputos só se contabiliza unha vez. Cando a persoa afectada xa morrera especificábase, polo regular, que a medida se adoptaba para efectos administrativos.

\footnotetext{
${ }^{31} \mathrm{~A}$ documentación sobre a composición da Comisión escasea, e nalgúns casos o único dato que posuímos é a sinatura das actas.

${ }^{32}$ Revisamos o boletín oficial provincial correspondente a 1943, 1944 e 1945, pero non conseguimos identificar máis persoas sancionadas.

${ }^{33} \mathrm{O}$ expediente deste mestre condenado a prisión pola súa pertenza á masonaría estaba pendente de resolución, segundo alertou en 1949 o delegado do Xulgado Superior de Revisións na Coruña ás autoridades centrais, que se apresaron a propoñer a súa separación definitiva no servizo (Archivo General de la Administración -en adiante, AGA-, 32/13335-30).

${ }^{34}$ Descoñecemos as resolucións ditadas verbo de dous mestres sancionados na primeira fase: Fernando Formoso Leis, mestre de Sequeiro (Valdoviño), e Manuel Rivero González, que estaba ao cargo da escola de Espasante (Ortigueira).

${ }^{35} \mathrm{O}$ criterio é discutible, especialmente no que respecta ás dúas primeiras sancións, pois unha suspensión de emprego e soldo por un mes pode resultar menos prexudicial que o traslado, poñamos por caso. Sexa como for, en táboas sucesivas deixaremos constancia de como se concretaban as sancións múltiples.

${ }^{36}$ Incluímos nas separacións unha inhabilitación perpetua (Brión) e dúas indefinidas (Muros e Vimianzo) que recaeron sobre mestres interinos. Un dos separados, José María Arán Trillo, foi rehabilitado para efectos administrativos. Sempre que non se sinale o contrario, nas táboas contabilizamos a primeira das sancións impostas.
} 
Táboa 3. Resultados do proceso de depuración (1937-1942)

\begin{tabular}{|c|c|c|c|c|c|c|c|c|c|}
\hline & \multirow[b]{2}{*}{ 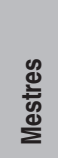 } & \multirow[b]{2}{*}{ 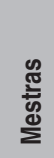 } & \multirow[b]{2}{*}{$\begin{array}{l}\text { 표 } \\
\text { 으 }\end{array}$} & \multicolumn{3}{|c|}{ Tipo de sancións (\%) } & \multicolumn{3}{|c|}{ Sancionados/as (\%) } \\
\hline & & & & 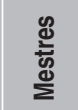 &  & 퓸 & 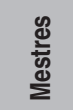 & 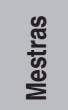 & 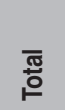 \\
\hline Separación definitiva & 152 & 19 & 171 & 38,97 & 16,38 & 33,79 & 17,97 & 2,07 & 9,69 \\
\hline Suspensión de emprego e soldo & 106 & 39 & 145 & 27,18 & 33,62 & 28,66 & 12,53 & 4,25 & 8,22 \\
\hline Traslado fóra de Galicia & 5 & 1 & 6 & 1,28 & 0,86 & 1,19 & 0,59 & 0,11 & 0,34 \\
\hline Traslado fóra da provincia & 55 & 14 & 69 & 14,10 & 12,07 & 13,64 & 6,50 & 1,53 & 3,91 \\
\hline Traslado dentro da provincia & 24 & 13 & 37 & 6,15 & 11,21 & 7,31 & 2,84 & 1,42 & 2,10 \\
\hline $\begin{array}{l}\text { Inhabilitación para cargos d. e } \\
\text { de c. }\end{array}$ & 1 & 0 & 1 & 0,26 & 0,00 & 0,20 & 0,12 & 0,00 & 0,06 \\
\hline Reposición con perda de haberes & 13 & 5 & 18 & 3,33 & 4,31 & 3,56 & 1,54 & 0,54 & 1,02 \\
\hline Reposición con dereito a haberes & 5 & 9 & 14 & 1,28 & 7,76 & 2,77 & 0,59 & 0,98 & 0,79 \\
\hline Sanción moral da publicidade & 4 & 2 & 6 & 1,03 & 1,72 & 1,19 & 0,47 & 0,22 & 0,34 \\
\hline Confirmación no cargo & 25 & 14 & 39 & 6,41 & 12,07 & 7,71 & 2,96 & 1,53 & 2,21 \\
\hline Total & 390 & 116 & 506 & 100 & 100 & 100 & 46,10 & 12,64 & 28,68 \\
\hline
\end{tabular}

Fonte: Elaboración propia a partir do BOP da Coruña e do BOE

Entre os mestres e mestras que xa foran sancionados na primeira fase, a separación definitiva afectou, en números redondos, ao $45 \%$, mentres que entre os que só o foron na segunda esta porcentaxe reduciuse ao 11\%. Dito doutra maneira, do total de persoas finalmente separadas, $089 \%$ foran previamente castigadas pola autoridade militar ou académica.

A suspensión de emprego e soldo por un determinado período de tempo representa 0 $28,66 \%$ das sancións e $08,22 \%$ dos sancionados ${ }^{37}$. Normalmente ía acompañada doutras medidas, como veremos.

Con porcentaxes moi inferiores aparecen o traslado fóra de Galicia, fóra da provincia ou dentro da provincia ${ }^{38}$. 0 primeiro, aplicado preferentemente aos que profesaban o galeguismo, era o que máis escaseaba, mentres que o segundo era o máis frecuente.

\footnotetext{
${ }^{37}$ Nesta medida inclúense cinco mestres e unha mestra que non tiñan escola en propiedade e foron inhabilitados para desempeñaren o ensino durante un certo tempo. Entre os suspendidos, José L. Soutelo Vázquez (Santiago) foi reposto con dereito a percibir os haberes non cobrados (BOP, 23/6/1938).

${ }^{38}$ Un dos trasladados fóra de Galicia, concretamente a Valladolid, Vicente Quintáns Castaño (BOP, 24/12/1937), conseguiu que se lle anulase o castigo pasados uns once meses (BOP, 11/15/1938).
} 
A inhabilitación para o desempeño de cargos directivos e de confianza como único castigo só foi adoptada nunha ocasión, e recaeu en Germán Castro Novo, mestre de Esmelle, no concello de Serantes (BOP, 9/3/1942).

Os mestres sancionados con perda dos haberes deixados de percibir ascenderon a 1839. A perda podía ser total (4 casos) ou de doce (1), seis (5), tres (6) ou un mes (2). Algo menos numerosos foron os repostos no cargo con dereito a percibir os salarios que deixaran de cobrar. Tanto a perda como o dereito aparecen sistematicamente como sanción única.

Se exceptuamos un caso correspondente a 1938, unha e outra medida só estiveron vixentes en 1937, e concentráronse nos últimos meses dese ano. Seguramente foron eliminadas por resultaren onerosas para a facenda pública. A reposición con perda parcial de haberes supuña o dereito a percibir os salarios correspondentes aos meses non penalizados, e así se recoñecía expresamente nalgunhas ordes: "Que dichos Maestros queden repuestos en sus cargos, con pérdida de un mes de los que dejaron de percibir y derecho a devengar los restantes, con cargo a los créditos que puedan habilitarse en su día", podemos ler verbo dunha listaxe en que aparecía a mestra de Santiago Sofía Pérez Sobral (BOE, 28/11/1937). A reposición con dereito a todos os haberes era aínda máis custosa para o Estado.

A catro mestres e dúas mestras sancionados con perda parcial dos haberes deixados de percibir foilles modificada a sanción por non levaren suspendidos o tempo suficiente para poder aplicar o castigo -de feito, na nosa investigación non aparecen na primeira fase do proceso de depuración-, e acordouse que "a todos los efectos sea suficiente la sanción moral de la publicación del castigo anterior" (BOP, 25/1/1938) ${ }^{40}$.

Os expedientes resoltos con todos os pronunciamentos a favor dos implicados, que quedaban confirmados no cargo -para efectos administrativos se xa finaran-, ou habilitados para exercer o ensino -no caso de cinco interinos-, suman 39 e supoñen $07,71 \%$ das resolucións ditadas e $02,21 \%$ do maxisterio público coruñés. Ora ben, todos estes mestres e mestras foron castigados na primeira fase, e ademais é moi posible que unha boa parte deles non recuperase os haberes deixados de percibir mentres durou a suspensión ou a destitución -moitas veces varios anos-, polo que deben ser rexistrados entre os sancionados. De feito, a decisión máis favorable das adoptadas na fase final, cando menos desde o punto de vista económico, posiblemente fose a reposición con dereito a haberes ou con perda parcial deles.

\footnotetext{
${ }^{39}$ No caso de Antonio Queiruga Fernández, mestre de Negreira, a perda do salario de seis dos meses deixados de cobrar (BOE, 28/11/1937) foi substituída pola suspensión de emprego e soldo durante tres meses (BOP, 25/1/1938).

40 Os seus nomes eran os seguintes: Antonio Puente Castro (Padrón), Francisco J. Paz Piñeiro (Curtis), Juan Manuel Pueyo García (Santiago), Pilar Pérez Hernández (Ferrol), Casilda Pavón Salgado (Melide) e Julio Pérez Uceda (A Coruña). Neste caso, ao se recoñecer na propia orde que non había marxe para aplicar a primeira sanción, computamos a segunda.
} 
A confirmación no cargo tamén foi a resolución que se adoptou respecto dos máis de mil mestres e mestras da provincia na Coruña que non aparecen na Táboa 3, pois, como é sabido, o proceso de depuración afectou a case todo o profesorado, por máis que nesta investigación decidimos centrarnos exclusivamente nas persoas que foron obxecto dalgún tipo de medida disciplinaria nalgún momento do proceso.

Se retornamos á Táboa 3 e reparamos nos seus valores porcentuais, obsérvanse importantes diferenzas entre homes e mulleres, como se ten subliñado repetidamente nos estudos realizados sobre a depuración noutras latitudes. No que respecta ao peso dos diferentes tipos de sanción, a máis común entre os primeiros era a separación -case catro de cada 10- e entre as mulleres a suspensión -unha de cada tres-. Se no tocante á sanción máis grave o peso dos mestres multiplica por máis de dous 0 das mestras, sucede 0 contrario coa confirmación no cargo, e sobre todo coa reposición con dereito á percepción de haberes, onde o factor multiplicador ascende a seis. As diferenzas son aínda máis contundentes se reparamos na porcentaxe de mestres e mestras sancionados: os separados multiplican case por nove as separadas, os suspendidos por tres as suspendidas e os trasladados fóra da provincia por catro as trasladadas. A porcentaxe feminina só supera a masculina na reposición con dereito a haberes, pois ao traballarmos unicamente co maxisterio sancionado nalgunha das dúas fases, onde os homes son amplamente maioritarios, tamén teñen máis peso na confirmación no cargo.

Así pois, os mestres foron máis castigados que as mestras, e tamén en maior medida. A explicación é clara: ao ser a depuración un proceso de natureza basicamente política, e dado que as mulleres tiñan aínda un escaso protagonismo neste ámbito, por máis que se estivese a incrementar nas datas que nos ocupan, resulta lóxico que as sancións se concentrasen nos mestres ${ }^{41}$. Ora ben, as mestras que asumiron un certo protagonismo político tamén foron sancionadas con contundencia, e mesmo asasinadas, como aconteceu con Mercedes Romero Abella (A Coruña) e María Vázquez García (Miño) ${ }^{42}$.

Segundo xa anticipamos, determinadas resolucións incluían varias medidas, de tal modo que á que podemos considerar principal se unían outras de carácter complementario. Comezaremos analizando as que acompañaban a suspensión de emprego e soldo, pero antes de o facer convén precisar a duración desta suspensión.

Segundo se pode apreciar na Táboa 4, o período máis usual era de dous anos para os mestres e de un mes para as mestras, diferenza que pon de manifesto, unha vez máis, a maior intensidade das sancións entre os primeiros. Para 20 homes e 8 mulleres, as ordes especificaban que se descontaría da duración da sanción o tempo de suspensión xa sufrido.

\footnotetext{
${ }^{41}$ Entre os traballos realizados sobre a incidencia do xénero na depuración, pode consultarse o de Juan Manuel Fernández Soria e María del Carmen Agulló Díaz, "Depuración de maestras en el franquismo", Studia Historica. Historia Contemporánea, n.ำ 17 (1999): 249-270.

${ }^{42}$ Sobre o protagonismo diferencial no ámbito político e sindical das mulleres e dos homes neste período, malia os avances das primeiras, cfr. Bernardo Maiz Vázquez, Amada García e os seus arredores (Ferrol: Edicións Embora, 2017), 32-36.
} 
Táboa 4. Duración da suspensión de emprego e soldo

\begin{tabular}{|c|c|c|c|c|c|c|c|c|c|c|c|c|c|c|c|c|c|c|}
\hline & \multicolumn{4}{|c|}{ Anos } & \multicolumn{5}{|c|}{ Meses } & \multicolumn{4}{|c|}{ Anos (\%) } & \multicolumn{5}{|c|}{ Meses (\%) } \\
\hline & 与 & ั̊ํํ & $\stackrel{\mathcal{E}}{\underline{2}}$ & $\frac{8}{\text { 언 }}$ & 与 & 음 & \&્르 & கூ & ङू & 与 & 옴 & \&્르 & 엉 & 与 & จั & \&્르 & $\frac{\mathscr{D}}{\mathscr{\infty}}$ & ङू \\
\hline Mestres & 23 & 37 & & 2 & & 2 & 31 & 10 & 1 & 22 & 35 & & 2 & & 2 & 29 & 9 & 1 \\
\hline Mestras & 7 & 10 & 1 & & 14 & & 2 & 5 & & 18 & 26 & 3 & & 36 & & 5 & 13 & \\
\hline Total & 30 & 47 & 1 & 2 & 14 & 2 & 33 & 15 & 1 & 21 & 32 & 1 & 1 & 10 & 1 & 23 & 10 & 1 \\
\hline
\end{tabular}

Fonte: Elaboración propia a partir do BOP da Coruña e do BOE

Agás 36 suspensións ditadas como sanción única, as restantes ían acompañadas practicamente todas da inhabilitación para o desempeño de cargos directivos e de confianza ${ }^{43}$, máis do $80 \%$ dalgún tipo de traslado, nomeadamente fóra da provincia, e arredor do 40\% da perda dos salarios que non se cobraran (Táboa 5). Para precisar a duración mínima do traslado fóra da provincia, as resolucións engadían que non se poderían solicitar destinos vacantes durante un certo período de tempo, que ascendía a cinco anos, agás en tres casos en que se reducía a dous ou a un. No tocante ao traslado dentro da provincia, só se concreta nunha ocasión a súa duración, que é tamén de cinco anos, os mesmos que para o único traslado fora de Galicia. Unha resolución típica desta modalidade de sanción sería a que recaeu en Felipa Andrade González, mestra de párvulos en Teixeiro (Curtis): "Suspensión de empleo y sueldo por dos años, traslado forzoso fuera de la provincia, con la prohibición de solicitar cargos vacantes durante un período de cinco años e inhabilitación para el ejercicio de cargos directivos y de confianza en instituciones culturales y de enseñanza" (BOP, 8/7/1940).

Táboa 5. Sancións asociadas á suspensión de emprego e soldo

\begin{tabular}{|l|l|l|l|l|l|l|}
\hline & Mestres & Mestras & Total & $\begin{array}{c}\text { Mestres } \\
(\%)\end{array}$ & $\begin{array}{c}\text { Mestras } \\
(\%)\end{array}$ & Total(\%) \\
\hline Ningunha & 22 & 14 & 36 & & \\
\hline Traslado dentro da provincia & 8 & 3 & 11 & 9,52 & 12,00 & 10,09 \\
\hline Traslado fóra da provincia & 58 & 18 & 76 & 69,05 & 72,00 & 69,72 \\
\hline Traslado fóra de Galicia & 0 & 1 & 1 & 0,00 & 4,00 & 0,92 \\
\hline Traslado (sen especificar lugar) & 2 & 1 & 3 & 2,38 & 4,00 & 2,75 \\
\hline Perda de haberes & 38 & 6 & 44 & 45,24 & 24,00 & 40,37 \\
\hline Inhabilitación para cargos directivos & 83 & 25 & 108 & 98,81 & 100,00 & 99,08 \\
\hline
\end{tabular}

Fonte: Elaboración propia a partir do BOP da Coruña e do BOE

${ }^{43}$ Rexístrase unha única excepción, a do xa mencionado José L. Soutelo Vázquez. 
Cando non se decretaba a suspensión, o traslado era a seguinte medida en orde de importancia, e normalmente tamén estaba asociada a outras que a complementaban ou concretaban.

Ao traslado fóra da provincia sumábase sempre a inhabilitación para o desempeño de cargos directivos e de confianza, e a súa duración era de cinco anos en aproximadamente oito de cada dez casos, sen que existan, en termos relativos, diferenzas notables en función do xénero.

$\mathrm{O}$ traslado dentro da provincia estaba sometido a unha maior variabilidade. A prohibición de solicitar vacantes durante un certo tempo só se especificaba no 38\% das ocasións, polo que esta sanción resultaba, en comparación coa anterior, algo menos dura e máis flexible, cando menos teoricamente. A inhabilitación para cargos apunta na mesma dirección, xa que só afectaba ao $57 \%$ dos trasladados. En sentido contrario, nun de cada tres casos deixábase constancia de que as persoas sancionadas perderían todos ou unha parte dos haberes deixados de percibir, aínda que esta circunstancia seguramente afectou a outras moitas para as que non se fixo explícita. Catro mestres e unha mestra recibiron como único castigo o traslado dentro da provincia.

Táboa 6. Duración en anos da prohibición de solicitar prazas vacantes nas sancións de traslado

\begin{tabular}{|l|c|c|c|c|c|c|c|c|c|}
\hline & \multicolumn{4}{|c|}{ Fóra da provincia } & \multicolumn{4}{c|}{ Dentro da provincia } & Fóra de Galicia \\
\hline & Cinco & Tres & Dous & Un & Cinco & Tres & Dous & Un & Cinco \\
\hline Mestres & 42 & 2 & 10 & 1 & 4 & 1 & 0 & 4 & 2 \\
\hline Mestras & 12 & 0 & 2 & 0 & 1 & 1 & 3 & 0 & 1 \\
\hline Total & 54 & 2 & 12 & 1 & 5 & 2 & 3 & 4 & 3 \\
\hline
\end{tabular}

Fonte: Elaboración propia a partir do BOP da Coruña e do BOE

Para dous dos mestres condenados a exerceren fóra de Galicia, ambos rianxeiros, non se determinaba por canto tempo estarían desterrados, aínda que si o lugar de destino: Palencia era o que agardaba a Germán Fernández Lemos (BOP, 24/12/1937) e Valladolid a Vicente Quintáns Castaño (BOP, 24/12/1937), mentres que para os tres restantes a duración estipulouse en cinco anos e non se rexistraba o destino: Arturo Arceo Fraiz (BOP, 9/3/1942), Horacio Fernández Gómez (BOP, 13/12/1940) e Emilia Cubeiro Castro (BOP, 5/8/1942), que exercían nos concellos de Santiago, Serantes e Narón, respectivamente. No tocante aos tres últimos, ao desterro uníase a inhabilitación para asumiren cargos directivos e de confianza, e no caso da mestra engadíase como penalidade adicional a perda dos haberes deixados de percibir. 
Táboa 7. Sumatorio das medidas

\begin{tabular}{|c|c|c|c|c|c|c|c|c|c|}
\hline & \multirow[b]{2}{*}{ 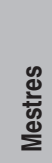 } & \multirow[b]{2}{*}{ 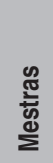 } & \multirow[b]{2}{*}{ 흉 } & \multicolumn{3}{|c|}{ Sancións (\%) } & \multicolumn{3}{|c|}{ Sancionados/as (\%) } \\
\hline & & & & $\begin{array}{l}\stackrel{\mathscr{L}}{\frac{2}{\not}} \\
\stackrel{\mathbb{d}}{\Sigma}\end{array}$ & 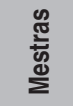 & 퓸 & 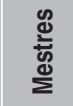 & 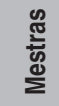 & $\begin{array}{l}\text { 퓨 } \\
\text { 음 }\end{array}$ \\
\hline Separación definitiva & 152 & 19 & 171 & 23,21 & 9,50 & 20,00 & 17,97 & 2,07 & 9,69 \\
\hline Suspensión de emprego e soldo & 106 & 39 & 145 & 16,18 & 19,50 & 16,96 & 12,53 & 4,25 & 8,22 \\
\hline Traslado fóra de Galicia & 5 & 2 & 7 & 0,76 & 1,00 & 0,82 & 0,59 & 0,22 & 0,40 \\
\hline Traslado fóra da provincia & 113 & 32 & 145 & 17,25 & 16,00 & 16,96 & 13,36 & 3,49 & 8,22 \\
\hline Traslado dentro da provincia & 34 & 17 & 51 & 5,19 & 8,50 & 5,96 & 4,02 & 1,85 & 2,89 \\
\hline Inhabilitación para cargos d. e de c. & 152 & 50 & 202 & 23,21 & 25,00 & 23,63 & 17,97 & 5,45 & 11,45 \\
\hline Reposición con perda de haberes & 59 & 16 & 75 & 9,01 & 8,00 & 8,77 & 6,97 & 1,74 & 4,25 \\
\hline Reposición con dereito a haberes & 5 & 9 & 14 & 0,76 & 4,50 & 1,64 & 0,59 & 0,98 & 0,79 \\
\hline Sanción moral da publicidade & 4 & 2 & 6 & 0,61 & 1,00 & 0,70 & 0,47 & 0,22 & 0,34 \\
\hline Confirmación no cargo & 25 & 14 & 39 & 3,82 & 7,00 & 4,56 & 2,96 & 1,53 & 2,21 \\
\hline Total & 655 & 200 & 855 & 100 & 100 & 100 & & & \\
\hline
\end{tabular}

Fonte: Elaboración propia a partir do BOP da Coruña e do BOE

A suma do conxunto das medidas que recaeron sobre os 506 mestres e mestras considerados ascende a $855^{44}$. Así as cousas, a máis habitual era a inhabilitación para 0 desempeño de cargos directivos e de confianza, seguida da separación, a suspensión de emprego e soldo e o traslado fóra da provincia -as dúas últimas con idéntico peso-, coas diferenzas por sexo que se poden apreciar na Táboa 7. Atendendo á porcentaxe de mestres e mestras que recibiron as sancións, a orde mantense, e as diferenzas entre uns e outras amósanse de forma máis contundente.

Como é sabido, unha porcentaxe importante dos sancionados solicitaron a revisión dos seus expedientes e conseguiron que se eliminase ou reducise o castigo. No caso dos separados, unha parte deles foron rehabilitados para exercer o ensino. Non obstante, a cuantificación dos resultados do proceso de depuración debe tomar en consideración unicamente, ao meu entender, as sancións ditadas polas autoridades militares, académicas ou ministeriais. Incluír neste cómputo as decisións adoptadas a raíz da revisión mistifica e mitifica a realidade. Polo demais, a revisión formaba parte do calvario que o fascismo lles reservaba aos mestres e mestras republicanos, como teremos ocasión de confirmar nos dous últimos apartados deste traballo.

\footnotetext{
${ }^{44}$ Non computamos a prohibición de solicitar prazas vacantes durante un determinado período de tempo por considerarmos que se trata dunha sanción asociada ao traslado.
} 


\section{A xeografía da represión}

A distribución das sancións debuxa un espazo heteroxéneo. Atendendo ao número de sancionados, rexístranse cinco concellos sen ningunha persoa castigada: Ares, Boqueixón, Cesuras, Oroso e Trazo, aos que se unen outros tantos cunha porcentaxe inferior ao 10\%: Aranga, A Capela, Cerceda, Mesía e Sobrado. Os máis castigados foron Carballo, Narón, Oza dos Ríos, Padrón e Vilarmaior, con valores que superan o 50\%, Corcubión, Camariñas e Muros, co $60 \%$ ou máis, e Melide, que acada un $77 \%$.

Táboa 8. Porcentaxe de sancións e separacións por concellos: homes (H), mulleres (M) e total (T)

\begin{tabular}{|c|c|c|c|c|c|c|c|c|c|c|c|c|c|}
\hline & \multicolumn{3}{|c|}{ Sancións } & \multicolumn{3}{|c|}{ Separacións } & & \multicolumn{3}{|c|}{ Separacións } & \multicolumn{3}{|c|}{ Sancións } \\
\hline & $\mathrm{H}$ & M & $\mathrm{T}$ & $\mathrm{H}$ & M & $\mathrm{T}$ & & $\mathrm{H}$ & M & $\mathrm{T}$ & $\mathrm{H}$ & M & $\mathrm{T}$ \\
\hline Abegondo & 44 & 0 & 18 & 22 & 0 & 9 & Mesía & 100 & 0 & 9 & 0 & 0 & 0 \\
\hline Ames & 47 & 11 & 33 & 20 & 0 & 13 & Miño & 38 & 13 & 25 & 25 & 13 & 19 \\
\hline Aranga & 13 & 0 & 7 & 0 & 0 & 0 & Moeche & 40 & 25 & 33 & 40 & 0 & 22 \\
\hline Ares & 0 & 0 & 0 & 0 & 0 & 0 & Monfero & 33 & 9 & 20 & 11 & 0 & 5 \\
\hline Arteixo & 36 & 17 & 29 & 27 & 17 & 24 & Mugardos & 44 & 0 & 25 & 22 & 0 & 13 \\
\hline Arzúa & 58 & 23 & 40 & 8 & 8 & 8 & Muros & 92 & 31 & 60 & 83 & 15 & 48 \\
\hline A Baña & 29 & 8 & 16 & 0 & 0 & 0 & Muxía & 38 & 30 & 33 & 25 & 20 & 22 \\
\hline Bergondo & 56 & 0 & 36 & 33 & 0 & 21 & Narón & 72 & 18 & 52 & 39 & 0 & 24 \\
\hline Betanzos & 40 & 0 & 22 & 10 & 0 & 6 & Neda & 27 & 0 & 19 & 0 & 0 & 0 \\
\hline Boimorto & 0 & 33 & 17 & 0 & 0 & 0 & Negreira & 44 & 10 & 26 & 11 & 0 & 5 \\
\hline Boiro & 44 & 8 & 23 & 33 & 0 & 14 & Noia & 44 & 30 & 37 & 11 & 0 & 5 \\
\hline Boqueixón & 0 & 0 & 0 & 0 & 0 & 0 & Oleiros & 65 & 21 & 45 & 35 & 7 & 23 \\
\hline Brión & 50 & 0 & 28 & 30 & 0 & 17 & Ordes & 20 & 0 & 11 & 20 & 0 & 11 \\
\hline Buxán & 25 & 0 & 14 & 0 & 0 & 0 & Oroso & 0 & 0 & 0 & 0 & 0 & 0 \\
\hline Cabana & 33 & 13 & 18 & 33 & 0 & 9 & Ortigueira & 67 & 12 & 41 & 30 & 0 & 16 \\
\hline Cabanas & 40 & 0 & 18 & 40 & 0 & 18 & Outes & 40 & 23 & 30 & 10 & 0 & 4 \\
\hline Camariñas & 67 & 60 & 64 & 17 & 20 & 18 & Oza dos Ríos & 70 & 25 & 57 & 10 & 0 & 7 \\
\hline
\end{tabular}

\footnotetext{
${ }^{45} \mathrm{O}$ número de mestres e mestras por concello está tomado, como xa dixemos, das nóminas cobradas polo maxisterio coruñés en xuño de 1936. A adscrición dos sancionados aos concellos realízase en función dos destinos recollidos nas disposicións sancionadoras da primeira e da segunda fase, contrastados, no seu caso, cos expedientes de depuración (AGA) ou co libro de movemento do persoal correspondente a estes anos (ARG), entre outras fontes. Case todos os sancionados aparecían na citada nómina no concello ao que aquí se adscriben, a pesar de que algúns, trasladados por esas datas, non cobraban aínda con cargo ao seu novo destino -este foi o caso de Fernando Barcia Beiras, destinado a Ameneiro-Calo (Teo) e ao que se lle pagaba a nómina pola escola de Ardagán (Santiago)-, e outros, particularmente aqueles que non foran sancionados inicialmente, serán nomeados posteriormente para os destinos que aquí se lles atribúen.
} 




Fonte: Elaboración propia a partir do BOP da Coruña e do BOE 
Pode afirmarse, nunha primeira aproximación, que as sancións abundan na costa e escasean no interior. Para concretarmos algo máis a distribución xeográfica, diferenciaremos as zonas en que afectaron cando menos ao 30\% do maxisterio, entre as que salientan dúas:

1. A primeira e máis ampla esténdese pola costa atlántica, entre Laxe e Ribeira, coa única excepción de Fisterra, e tamén polos concellos de Vimianzo, Mazaricos e Outes.

2. A segunda abrangue, sen solución de continuidade, os sete concellos que se asoman ao mar entre Ferrol e Mañón ${ }^{46}$, con prolongacións cara ao interior en San Sadurniño e Moeche.

Existen outras catro áreas de menor extensión, formadas por agrupacións de dous ou tres concellos: Padrón, Dodro e Rianxo; Oleiros, Cambre e Bergondo; Arzúa, Melide e Toques; e Coirós e Irixoa. $O$ resto dos casos que superan a porcentaxe sinalada aparecen illados: Carballo, Vilarmaior, Curtis, Vedra e Ames.

$\mathrm{Na}$ Coruña central e interior, pola contra, a porcentaxe de maxisterio sancionado foi, coas excepcións que deixamos consignadas, bastante inferior, e con frecuencia situábase por debaixo do $20 \%$.

Por sexos, os concellos sen mestres sancionados suman oito, mentres que as sancións superan o $50 \%$ en $14,060 \%$ en 13 e o $70 \%$ en $11^{47}$. No tocante ás mestras, non se rexistra ningunha sancionada en 38 , e só están por riba do $50 \%$ Camariñas, Corcubión e Melide. Con todo, as mulleres recibiron porcentualmente máis sancións que os homes en Boimorto, A Capela, Corcubión, Frades, Melide e Paderne.

Vexamos, daquela, o que aconteceu en Melide, o concello onde, en termos relativos, houbo máis sancións, máis mestras represaliadas ${ }^{48} \mathrm{e}$ estas superaron os mestres.

010 de agosto de 1936, o xefe local, o xefe de milicias e o xefe de propaganda de Falanxe déronse présa en remitir ás autoridades provinciais, nun escrito asinado conxuntamente, os informes sobre o maxisterio que lles foran solicitados dous días antes a través do BOP, e o día 20 envíano de novo, temerosos de que se extraviara, segundo declaraban, e seguramente ansiosos por non teren noticias ao respecto. Nel facíase constar que debían ser destituídos a perpetuidade Manuel Rey Ferreiro, Gerardo Brea Rodríguez e Manuel Vidal Conde, todos eles socialistas, propagandistas e de acción, e o primeiro defensor dunha escola "anticristiana, antiespañola y antimoral", e tamén Pastor Barral Camoiras, afiliado á Asociación de Traballadores do Ensino (ATE). Outros cinco mestres e dúas mestras fixeran méritos para seren suspendidos de emprego e soldo entre tres meses e un ano: Nilo Cea

\footnotetext{
${ }^{46}$ Actualmente seguen a ser sete, xa que a integración de Serantes en Ferrol foi compensada pola segregación de Cariño de Ortigueira.

${ }^{47}$ A porcentaxe do 100\% de Mesía non resulta moi relevante, pois só había un mestre. Mulleres, pola contra, había 10, e ningunha resultou sancionada

${ }^{48}$ Matematicamente sería Corcubión, mais este pequeno concello só contaba cunha mestra, polo que non resulta moi representativo para estes efectos.
} 
Rodríguez, galeguista; Cándido Paz Ares, que ata o 16 de abril fora "derechista y por pancista se fue con las izquierdas"; Marcial García Suárez, membro de Unión Republicana; Amós Illana García e Jesús Rivas Rodríguez, votantes das esquerdas, aínda que non pertenceran a ningún partido; Pilar Sanz Martínez, "muy simpatizante con el Frente Popular"; e María López Chorén, "muy simpatizante con las izquierdas." O resto do maxisterio -seis mestres e cinco mestras- era de dereitas, ao entender dos novos amos do concello ${ }^{49}$.

As autoridades superiores, en ordes publicadas 019 e 27 de agosto e 015 de setembro de 1936 no BOP, ativéronse á proposta da Falanxe, cunha única excepción, a de María López Chorén, a quen non se estimou oportuno castigar. Na segunda fase do proceso de depuración, dous dos catro destituídos foron separados definitivamente do ensino -a Barral Camoiras aplicóuselle a suspensión de emprego e soldo por un ano e a Rey Ferreiro por dous-, e dos seis suspendidos, unha foi privada do exercicio do ensino por un ano (Sanz Martínez), un trasladado fóra de Galicia (García Suárez), tres repostos no seu cargo con perda dos haberes deixados de percibir (Cea Rodríguez, Paz Ares e Rivas Rodríguez) e un confirmado no cargo (Illana García). Polo demais, as autoridades ministeriais sancionaron catro mestras que non resultaran afectadas na primeira fase (María Socorro Sarandeses Martínez, Rufina Rey Rodríguez e Peregrina López Iglesias, suspendidas por un mes, e Casilda Salgado Pavón, reposta no cargo con un mes de perda de habere $\mathrm{s}^{50}$ ) e dous mestres, José Reinoso Carreira e José Hermida Piñeiro, suspendidos por tres meses. En relación con María López Chorén, acordouse confirmala no cargo e deixar sen efecto o traslado anteriormente imposto, polo que parece que nalgún momento recibiu este tipo de sanción ${ }^{51}$.

A porcentaxe de mestres separados definitivamente do ensino neste concello cifrábase no $13 \%$, sensiblemente inferior á media galega (18\%) e a moita distancia dos que quedaron privados de cando menos a metade dos seus efectivos (Cambre, Cee, Muros, Valdoviño e Vilasantar), o 40\% (Cabanas, Moeche e Vimianzo) ou o 30\% (Bergondo, Boiro, Brión, Cabana, Carballo, Carnota, Cedeira, Culleredo, Ferrol, Mazaricos, Narón, Oleiros e Ortigueira). As mulleres, como xa sabemos, sufriron en menor medida esta penalidade, $\mathrm{e}$ as porcentaxes de afectadas máis altas oscilan entre 010 e 0 20\% en Arteixo, Camariñas, Miño, Muros, Muxía, O Pino, Somozas e Valdoviño.

Centraremos agora a nosa atención en Muros, onde a intensidade das represalias resultou ser máis alta: foron separados do ensino 10 dos 12 mestres (o 83\%, a cifra máis elevada de toda a provincia) e dúas das 13 mestras $^{52}$.

\footnotetext{
${ }^{49}$ A relación forma parte do expediente de depuración de José Brea Rodríguez, AGA, 32/13331-20.

${ }^{50}$ Esta última sanción fíxose pública no BOE 0 28/11/1937, e dous meses despois acordouse rectificala, por se considerar suficiente coa "sanción moral" que representara a publicación do castigo anterior (BOP, 25/1/1938).

${ }^{51}$ Parece que algunhas sancións de traslado ditadas na primeira fase non foron publicadas no BOP. Rosario Romero Abella, por exemplo, declaraba, en escrito dirixido ao reitor (14/10/1936), que 029 de agosto fora "sancionada" co traslado desde Arteixo a Santa Comba, e posteriormente con suspensión de emprego e soldo por un ano, mais só aludía á publicación desta última sanción (BOP, 15/9/1936), que é a computada nestas páxinas (AGA, 32/12517-26).

${ }^{2}$ Para máis información sobre a depuración neste concello, véxase Costa Rodil e Santos Suárez, "De Padrón a Muros", 75-80.
} 


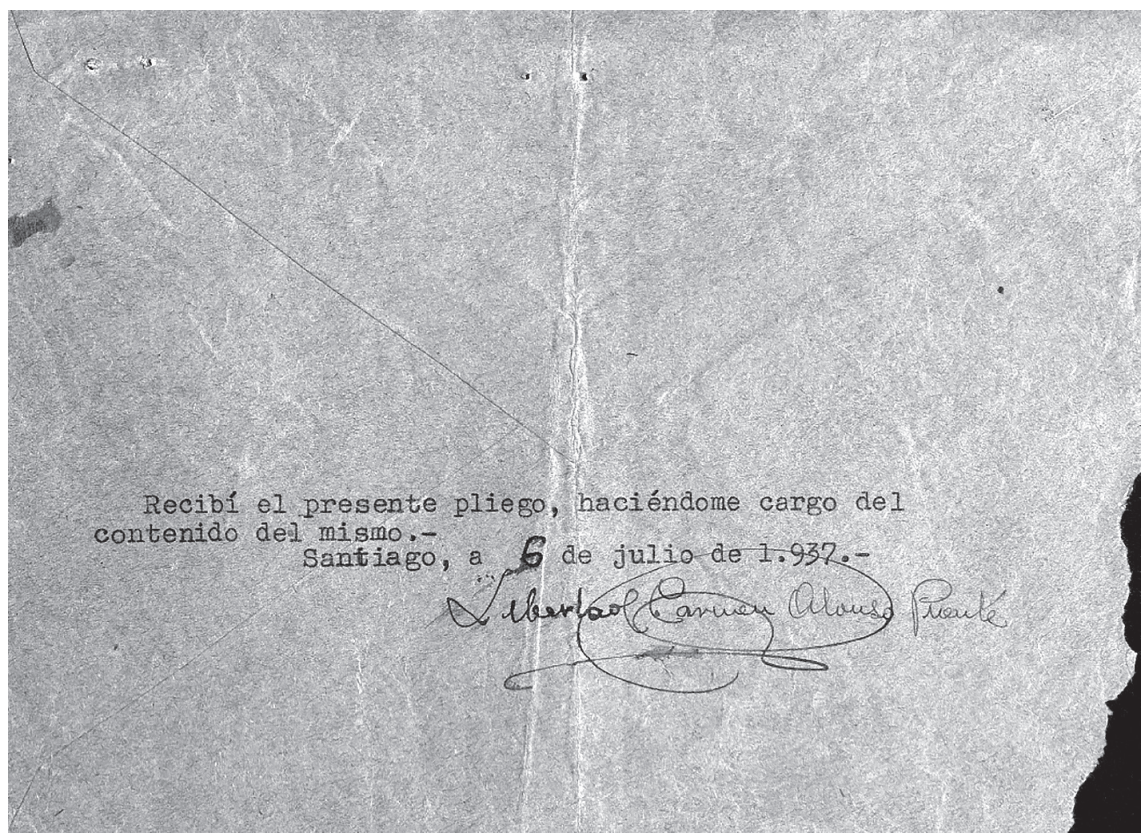

3. Libertad Carmen Alonso Puente, mestra de Esteiro (Muros), asina a recepción do sobre que contiña o prego de cargos, un dos cales era o de aumentar o nome de Carmen co de Libertad. Tivo que presentar un certificado de nacemento para demostrar que non era así. Na sinatura a palabra máis rotunda é sen dúbida Libertad (AGA, 32/12511-13).

A Garda Civil caracterizaba así a ideoloxía dos mestres nun informe datado 028 de agosto $^{53:}$ Francisco Rodríguez Suárez, José Ballesta Serrano, José Tobío Mayo, Joaquín Fernández Cambeiro, Andrés Sánchez Toro, José Álvarez López Brenlla, Manuel Alonso Asorey e Paulino Núñez Arenas eran definidos como socialistas, aínda que nalgún caso a adscrición non semella ser moi precisas4; sobre Rafael Pardo Carmona, que acababa de tomar posesión da nova escola que lle fora asignada, dicíase carecer de antecedentes -nunha nota manuscrita alguén fai saber que era "muy peligroso, de ideas comunistas. Preso en la Cárcel de Santiago"55-; por último, José Beiro Uhia, Alejandro Castiñeira Rodríguez e Benancio [sic] Pérez Barreiro eran cualificados como dereitistas e simpatizantes dos militares. Respecto dos esquerdistas, sirva como exemplo a descrición que se ofrece de José Ballesta Serrano:

\footnotetext{
${ }^{53}$ Expediente de depuración de José Ballesta Serrano, AGA, 32/12510-02.

${ }^{54}$ José Tobío Mayo e Manuel Alonso Asorey, por exemplo, seguramente fosen simpatizantes ou militantes de Izquierda Republicana. 0 segundo era catalogado como lugartenente do primeiro -"el maestro más peligroso de la comarca"- e coñecido co alcume de Casares Quiroga.

${ }^{55}$ Será fusilado en Compostela 03 de decembro de 1936 (véxase a base de datos Nomes e Voces, que 0 adscribe a Izquierda Republicana: http://www.nomesevoces.net/).
} 
Regenta la escuela de Louro, pertenece al partido socialista, propagandista especial en las elecciones que apoyó al Frente Popular, siendo el Jefe del mismo en la parroquia de Louro, donde tenía un foco de propaganda comunista y antirreligiosa en el pósito marítimo de cuya escuela es el maestro. Desde el advenimiento de la república, fue el principal agente de divulgación de toda idea subversiva contra el orden social y religioso. No cumplía con su deber en la escuela en lo concerniente a la asistencia, toda vez que la abandonaba con frecuencia para hacer viajes a Asambleas de pósitos sin pedir la correspondiente licencia, por lo que dio origen a que se le expedientase en una ocasión. Posesionado de la otra escuela de niños que existe en Louro el maestro Don Jesús Álvarez López Brenlla, este y el Ballesta venían frecuentemente a Muros para tratar con sus camaradas de asuntos políticos y sociales.

En la escuela inculcaba a los niños el desprecio a la religión católica, preguntándole[s] muchas veces para que iban a misa y para que rezaban el rosario, que si por existir [sic] a dichos actos les daban algo. Les hablaba también del sistema y enseñanzas de Darwin. Está muy mal visto en la parroquia. El día de Santiago vino a Muros con unos del Pindo diciendo que iban a defender a sus camaradas.

Entre as mestras, invertíase a relación, xa que nove eran adscritas ás dereitas (Josefa Bouzas Lestón, Dolores Fernández González, María Luísa García P., María César Rodríguez, Consuelo Raposo, Carlota Vaz Gallego, Juana Beiro Uhia, Rosalía Fernández González e Petra Lojo) e só catro das esquerdas: María Membiela Rodríguez era socialista, aceptara a radio que lle ofrecera o alcalde da Fronte Popular coa promesa de que sintonizaría Radio Madrid, acollera na súa casa seis fuxidos e, en compañía da tamén mestra Sofía Mesejo Vázquez, cantaran a Internacional durante un paseo que realizaran coas súas alumnas; María Agustina Rico Lago non fixera propaganda frontepopulista, mais simpatizaba coas esquerdas e deixara de asistir á igrexa desde que os esquerdistas gañaran as eleccións; e Carmen Libertad Alonso Puente fora "propagandista en las últimas elecciones del Frente Popular, simpatizante con el comunismo, es muy inmoral y ha llegado a decir que antes de gritar Viva España, consentiría la muerte."

Na primeira fase do proceso de depuración foron destituídos oito dos nove mestres definidos como esquerdistas -José Fernández Cambeiro resultou suspendido de emprego e soldo- e mais as catro mestras que recibiron idéntica cualificación. Na segunda fase acordouse separar definitivamente do ensino os nove mestres xa mencionados e dúas mestras, Membiela Rodríguez e Alonso Puente. A maiores, foi inhabilitado para o exercicio do ensino Joaquín Barreiro Paradela, designado mestre interino da escola para a que fora nomeado Rafael Pardo Carmona, e sobre o que non se adoptara inicialmente ningunha medida.

Muros quedaba así privado de case todos os seus mestres. Serán substiuídos por outros que exhibirán como principais méritos os contraídos na guerra e a adhesión á ideoloxía do denominado Movemento Nacional. Sirvan como exemplo os concursos para cubrir interinidades, en que se utilizarían os seguintes criterios para a adxudicación das prazas (BOE, 26/8/1938): ser mutilado como consecuencia da guerra, sempre que a mutilación non inhabilitase para o exercicio do ensino; resultar ferido na guerra, circunstancia que se valoraría atendendo ao número de feridas que se demostrasen; ser ex-combatente na Cruzada; sufrir prisión ou aldraxes graves por parte dos "rojos"; ser familiar dun morto ou mutilado na Campaña ata o segundo grao de parentesco por consanguinidade ou afinidade, criterio cuxa valoración dependería da cantidade de perdas sufridas; no mesmo grao de parentesco, número de mortos "por asesinato de los rojos o a consecuencia de 
su barbarie"; ser familiar, tamén en idéntica modalidade de parentesco, dalgún preso ou mutilado polos "rojos"; sufrir importantes perdas materiais a causa da guerra; posuír o certificado de asistencia ao Cursiño de Orientacións Nacionais celebrado en Pamplona en 1938; anos de servizos no maxisterio; data en que se remataran os estudos e, en caso de empate, a idade. Amén.

\section{Xosé Toba Fernández: "En sí mismo, con los niños y en todas sus actuaciones, refinadamente malo, perverso y revolucionario"}

O protagonista da nosa primeira historia, nacido en Muxía 08 de setembro de 1904, obtivo o título de mestre en 1925, e tamén posuía o de bacharel, que non constituirá un requirimento para cursar o maxisterio ata $1931^{56}$. En 1926 iniciou a súa andaina profesional, e exerceu en varias escolas, como a de Sillobre (Fene), onde permaneceu durante catro anos. Andando o tempo opositou á dirección de escolas graduadas, e logo de pasar algúns meses á fronte da escola de Callosa d'en Sarrià (Alacante), en xuño de 1934 conseguiu por concurso a rexencia da graduada anexa á Escola Normal de Santiago. 021 de xaneiro de 1935 foi nomeado profesor axudante de Pedagoxía da Normal compostelá, e como tal fíxose cargo en 1936 dos seminarios de carácter pedagóxico, e posteriormente da materia de Paidoloxía e Organización Escolar. Foi tamén en 1935 cando publicou un breve opúsculo titulado Problemas que nos plantea la Escuela y el Niño en Galicia, en que defende, entre outras cuestións, a utilización do idioma galego nas aulas ${ }^{57}$. 0 ensaio reproduce 0 seu discurso de ingreso na Sección de Pedagoxía do Seminario de Estudos Galegos, e o seu contido debuxa de forma esquemática as liñas de actuación da devandita sección ${ }^{58}$.

Como xa sabemos, en agosto de 1936 foi declarado pola Delegación Militar excedente forzoso con dereito a percibir dous terzos do soldo, sanción absolutamente atípica, pois é o único caso desta natureza que atopamos, e máis adiante separado do ensino na súa condición de axudante de Pedagoxía (maio de 1937) (59 $^{59}$ de mestre (xullo de 1940). Deseguido, examinaremos o expediente que está na orixe desta última sanción.

A Comisión depuradora fíxolle chegar un prego con sete cargos, datado 024 de abril de 1937. Como o seu destinatario non estaba no domicilio compostelán ao que foi enviado, houbo que requirilo, como adoitaba suceder nestes casos, a través do BOP (1/6/1937)

\footnotetext{
${ }^{56}$ Os datos corresponden, sempre que non se sinale outra procedencia, ao expediente de depuración: AGA, 32/13337-27.

${ }^{57}$ A Coruña, Tip. El Noroeste, 1936. Este opúsculo formaba parte das publicacións promovidas pola revista coruñesa Vanguardia Pedagógica. 0 texto reprodúcese como anexo en Antón Costa Rico, A reforma da educación (1906-1936). X. V. Viqueira e a historia da Psicopedagoxía en Galicia (Sada: Ediciós do Castro, 1996). ${ }^{58}$ Xosé Ramón García Soto, "Antecedentes da psicoloxía infantil en Galicia: a Sección de Pedagoxía e o Laboratorio de Psicotecnia do Seminario de Estudos Galegos", Sarmiento. Anuario Galego de Historia da Educación, n.ำ 17 (2013): 113-144. Nesta mesma revista, véxase tamén Antón Costa Rico, "O Seminario de Estudos Galegos: laboratorio dun plan pedagóxico para Galicia”, n.ำ14 (2010): 27-49.

${ }^{59}$ Sobre a depuración do profesorado normalista santiagués, véxase Aurora Marco e Anxo Serafín Porto Ucha, A Escola Normal de Santiago de Compostela: de Escola Normal Superior a Escola Universitaria (1849-1936) (Santiago: USC, 2000), 150-154.
} 
para que comunicase cal era a súa residencia. De non o facer, o expediente continuaría a súa tramitación sen as xustificacións que puidese alegar na súa defensa. Os cargos, todos eles gravísimos segundo os baremos dos golpistas, eran os seguintes:

1․ Haber pertenecido como Concejal a la Corporación municipal de Santiago, después del 18 de febrero del 36, en calidad de miembro del Frente Popular, ostentando la representación del galleguismo de izquierdas.

2‥ Haber organizado un homenaje a D. Marcelino Domingo.

3ํ. Haber laborado como Concejal para que fuesen clausurados los colegios de la Compañía de María (Enseñanza) y de la Doctrina Cristiana.

$4^{\circ}$. Haberse mostrado en sus enseñanzas hostil al amor y respeto debido a las instituciones sociales básicas: familia, patria, religión, etc.

5‥ Haber hecho propaganda a favor del Estatuto gallego.

6ํ․ Haber hecho propaganda comunista y revolucionaria entre sus alumnos.

7ํ. Haber pertenecido a la Federación de Trabajadores de la Enseñanza.

Os cargos baseábanse nos catro informes regulamentarios e nun informe adicional. Segundo o alcalde compostelán, Manuel García Diéguez, o encausado orientaba o ensino nunha dirección antiespañola e contraria ás institucións básicas da civilización, pertencera ao Partido Galeguista e fora concelleiro da Fronte Popular na propia cidade. O comandante do posto da Garda Civil pensou que se trataba dun alumno da Escola Normal -no canto dun mestre da escola anexa á Normal-, e como non exercera en Santiago, manifestaba que nada podía dicir acerca del. O pai de familia, Ramón González, no informe colectivo que elaborou sobre o maxisterio compostelán, aludía aos tres primeiros cargos, e tamén a que cotizara 50 céntimos mensuais para axudar os mestres presos en Asturias a raíz dos sucesos revolucionarios de 1934, acusación que, sorprendentemente, non rexistra a Comisión, malia o facer noutros moitos expedientes. "En resumen: de lo peor. Se afirma que ha sido declarado excedente con 2/3 del sueldo. ESTO NO PUEDE SER." O párroco de San Frutuoso, Valentín Losada Vázquez, non precisa recorrer ás maiúsculas para facer unha descualificación global do noso mestre e redactou un deses refinados informes que merecen ser reproducidos na súa integridade:

1‥ Conducta profesional - Malísima = Toda ella se dirigía a hacer comunistas y revolucionarios a los alumnos. Así que en todo dejaba que desear. - Socavaba, teórica y prácticamente, los fundamentos de Religión, Estado, Sociedad, Humanidad, hasta en los ejercicios y movimientos de los niños, en la Escuela.

$2^{2}$. Conducta social - Pésima y de funestas consecuencias. - Siempre encaminada a hacer prosélitos para el anarquismo y la revolución social.

3‥ Particular - Mala también, pues no gozaba sino asistiendo a Centros de gentes subversivas; y su ejemplo y excitaciones, siempre hacia el mal y la destrucción de la sociedad actual.

4․ Política - Refinadamente izquierdista. Propagandas revolucionarias y comunistas, las suyas. Perteneció a las sociedades laicas y más perversas. Fue de "Trabajadores de la Enseñanza" y destacado, con cargos, en el Frente Popular.

En sí mismo, con los niños y en todas sus actuaciones, refinadamente malo, perverso y revolucionario. 
O informe adicional correspondía a Manuel Eiras Blanco, mestre da sección primeira da escola graduada que tiña a Toba como director-rexente. Declaraba actuar atendendo a un deber patriótico e en obediencia ás disposicións vixentes. Quería contar unha historia, que dicía así: a mediados do curso 1935-1936, Toba presentouse na súa aula e levou para o despacho de dirección tres ou catro nenos, escollidos entre os máis pequenos, que regresaron aproximadamente media hora despois. A operación repetiuse varias veces, e como non era informado dos motivos aos que obedecía, o dicente, aínda que preocupado, non fixo ningunha pregunta nin comentario ao respecto, pois os tempos eran os que eran e grandes as súas diferenzas ideolóxicas co director. Así que optou por sufrir en silencio -a esta altura do relato, un xa teme o peor-. O tempo foi pasando, ata que un día do mes de novembro do seguinte curso académico, ao entrar na clase, despois de se ver obrigado a saír por mor dunha necesidade apremante, soubo que un dos nenos que no seu día acompañaran o director ao seu despacho, aproveitando a ausencia do mestre, "se levantó, en plena clase, según me manifestaron todos los niños que había en clase, levantó el puño y dio viva al comunismo". O neno foi reprendido, e ao lle preguntar quen lle aprendera, contestou que fora don Xosé. Outros alumnos que participaran da mesma experiencia dixeron o mesmo, e algún confesou que tamén foran instruídos no despacho do director nenos que non pertencían á anexa.

A Comisión depuradora do maxisterio, que era a D, solicitou informes da C, encargada da depuración do profesorado das escolas normais, e xa que logo do noso protagonista na súa condición de axudante de Pedagoxía. O seu secretario, Jesús Babío Calleja, remitiu tres certificados. No primeiro afirmábase que Xosé Toba aparecía nunha fotografía -existente no expediente do inspector de ensino primario Manuel Díaz Rozas ${ }^{60}$ - da asemblea celebrada para fixar a data "de celebración [da votación] del Estatuto Gallego". No segundo reproducíase a información da Comisaría de Investigación e Vixilancia de Santiago sobre Toba, incorporada ao expediente de Matilde Díaz y Saiz, profesora da Escola Normal compostelá: tratábase dun elemento de "ideología anti-españolista" que se distinguía "por su sectario separatismo e íntima relación con las extremas izquierdas." Finalmente, no terceiro, remitíase un certificado do secretario do concello de Santiago -formaba parte do expediente de depuración de Toba como axudante- segundo o cal o encausado fora designado membro da nova corporación municipal constituída o 23 de febreiro, na cal exercía o cargo de tenente alcalde.

Na documentación sobre de Toba tamén se conserva unha nota con varias alusións á súa persoa, extraídas do expediente de depuración do inspector Luciano Seoane. Un dos declarantes afirmaba que este inspector canalizaba "sus trabajos marxistas" a través dos sig-

\footnotetext{
${ }^{60}$ En relación con este inspector e a biblioteca que formaron el e a súa dona, a tamén inspectora Cristina Pol, véxase Antón Costa Rico, "La biblioteca que guardaron las gaviotas. Memoria bibliográfica de dos inspectores republicanos", Historia de la Educación. Revista Interuniversitaria, n.ำ 17 (1998): 445-451.
} 
nificados mestres Toba, Barcia ${ }^{61}$ e Moratinos ${ }^{62}$, cos que se reunía acotío e dos que se servía para facer propaganda da Federación Española de Traballadores do Ensino (FETE) entre os alumnos e as alumnas da Escola Normal, propósito en que tamén colaborou un deles, de nome Rastrollo63. A súa actuación foi eficaz, e conseguiron que "gran parte de los chicos se pervirtiesen y sintiesen simpatías por los ideales socialistas y comunistas". Todo isto

puede testimoniarlo Da María Teresa Ayú de Mon del Rivero, que con energía muy digna de encomio, persuadió a distintas alumnas de la Escuela Normal para que no ingresaran en una agrupación masónico-marxista fundada por el Sr. Seoane, el Sr. Toba (ya destituido) y Rastrollo (ahora procesado). Ha sido fusilado Rastrollo -engade o transcritor- por sentencia de consejo de guerra.

Nos descargos, redactados o 17 de xuño de 1937, o mestre negaba, ou cando menos matizaba, as acusacións de que era obxecto. Non podía negar a súa condición de concelleiro e terceiro tenente alcalde da corporación municipal compostelá ${ }^{64}$, mais argumentaba que se trataba dun cargo que non procurara -carecía de ambicións políticas e de tempo para dedicar a este tipo de ocupacións-, que resultaba incompatible coa súa situación profesional, que a súa actuación como tal se centrara nos asuntos escolares e que presentara a dimisión 01 de xuño65. E desde logo nada tiña que ver coa Fronte Popular. $\mathrm{Na}$ corporación estivera en representación do galeguismo, mais non da esquerda:

Y debe declarar, en honor a la verdad, que su inclinación hacia el "Galleguismo" nacía del deseo del mejoramiento de Galicia, siempre dentro de la unidad de España, de acuerdo con el programa del partido, de carácter autonomista, y rechazando el calificativo de "izquierdas", que se añade a su representación galleguista, por ser una aseveración gratuita, pues el Partido carecía de tal denominación y significado del izquierdismo, y mal podría representar el recurrente esa tendencia ${ }^{66}$.

Non participara en ningunha homenaxe a Marcelino Domingo, nin era coñecedor de que se celebrara en Santiago un acto neste sentido, aínda que contribuíra coa súa cota a sufragar a edición dun libro sobre os problemas da escola e do mestre escrito polo ex-ministro, iniciati-

\footnotetext{
${ }^{61}$ Fernando Barcia Beiras (ou Veiras, dependendo das fontes) era un mestre socialista que o 16 de xullo de 1936 tomou posesión da escola de Ameneiro-Calo (Teo); procedía da escola de Ardagán (Santiago). Foi presidente do Comité de Defensa da República en Compostela, xulgado en consello de guerra e executado. Véxase Luís Lamela García, 1936, la "Cruzada" en Compostela. La Guerra Civil y la represión franquista en los documentos civiles y militares (Sada: Ediciós do Castro, 2005), 254-268 e passim. Tamén foi depurado e separado do ensino (AGA, 32/12510-40).

${ }^{62}$ Pedro Alejandro Sánchez Moratinos era mestre do Sar (Santiago). Foi inicialmente destituído polas autoridades militares e o seu proceso de depuración concluíu co traslado fóra da provincia por cinco anos (AGA, 32/12525-6). ${ }^{63}$ Supoñemos que se trataría de Luís Rastrollo González, mestre e principal dirixente do Partido Obreiro de Unificación Marxista (POUM) en Galicia. Tamén formou parte do Comité da Defensa da República de Santiago, polo que foi xulgado e executado. Véxase Lamela, 1936, 285-286 e passim. No BOP do 24 de agosto inhabilitábase para o exercicio do ensino durante dous anos ao "maestro del grado profesional" Demetrio Pérez Rocha, mais ao día seguinte desfacíase o erro: a quen se quería inhabilitar era ao alumno da Escola Normal de Santiago Luís Rastrollo González, que non podería cursar estudos neste centro durante un ano.

${ }^{64} \mathrm{Na}$ prensa da época quedou constancia da súa actuación como concelleiro, así como do uso que facía do idioma galego nas sesións municipais, ao igual que outros compañeiros, entre eles o propio alcalde, Ánxel Casal. ${ }^{65}$ No certificado do secretario do concello compostelán xa citado afirmábase que na sesión celebrada 09 de xullo se lera un escrito segundo o cal Toba e outros presentaran a súa dimisión ante o gobernador civil, mais a autoridade provincial nada resolvera, polo que a corporación non experimentara cambios.

${ }^{66}$ A argumentación tiña escasas posibilidades de prosperar, pois a Comisión consideraba, e así o fixo constar en varias ocasións, que na provincia da Coruña o único galeguismo operativo fora o de esquerdas.
} 
va adoptada pola Asociación Nacional do Maxisterio para agradecer as benéficas actuacións deste a prol dos mestres e mestras, e carente de toda significación política. Non tivera ningunha intervención especial no proceso de substitución das congregacións relixiosas no ensino, alén de se reunir coa Inspección, na súa condición de membro da Comisión Municipal de Instrución Pública, para tratar sobre este proceso, tal como estaba legalmente estipulado; así o podían testemuñar as dúas institucións mencionadas nos cargos, que ademais non viron interrompida a súa actividade escolar. Tampouco estivera ao seu cargo ningunha sección da escola graduada, polo que malamente podía ser acusado de contrariar coa súa actuación docente as institucións básicas da civilización; se algunha influencia exercera neste sentido sería na súa condición de director, e estaría canalizada a través dos catro mestres encargados das clases: Eiras, Abeijón, Pueyo e Lamelo, "personas de reconocida significación derechista y de toda solvencia católica. Ninguno de ellos, de ser preguntado sobre el particular, podría hacerse solidario de esas malévolas imputaciones. Algunas veces, el dicente ha dado lección a los niños de uno u otro grado, pero siempre ante el maestro correspondiente y los alumnos del Magisterio que allí realizaban sus prácticas"; e remataba este descargo engadindo que podía presumir dunha conduta familiar e cidadá que "seguramente, no podrá superar el delator que tan malévola e injustamente me acomete." En relación co Estatuto, opta por dicir o menos posible, que era sen dúbida o mellor camiño para quen asinara un manifesto no seu apoio uns meses antes: "Nadie podrá probar que haya concurrido el dicente a acto público alguno como encargado de propagar el Estatuto Gallego" ${ }^{\prime 67}$. Sobre a suposta propaganda comunista e revolucionaria realizada entre os alumnos, pide ao "malévolo delator" que concrete os feitos e presente as probas, solicita que algún membro da Comisión depuradora se presente en Santiago para investigar as prácticas que se lle apoñen e manifesta o seu desexo dunha confrontación dialéctica co delator, se tal circunstancia estaba prevista neste tipo de procesos. Finalmente, e en relación co asociacionismo profesional, recoñecía que militara na FETE e na Asociación Nacional do Maxisterio de Ferrol, das que se dera de baixa ao trasladarse a Alacante, e que ao retornar a Galicia só causara alta na Asociación de Mestres do Partido de Santiago, filial da Nacional.

Os descargos foron ampliados trece días máis tarde, argumentando agora que sobre súa conduta se podía solicitar o testemuño do reitor do Seminario -cursara estudos nesta institución-e doutras acreditadas persoas de Santiago, cidade pequena, e onde as faltas que se lle apuñan sen dúbida serían coñecidas, caso de seren certas. A estes posibles testemuños uníanse os que xa achegara, asinados polos párrocos de Muxía e de Sillobre. Coma outros moitos depurados, vese obrigado a multiplicar as probas que o poidan congraciar coas novas autoridades, polo que considera oportuno lembrar que no comentario escrito sobre a liberdade e a autoridade na escola, realizado nos exercicios de oposición á dirección de escolas graduadas que tiveran lugar na Coruña en 1933, defendera "la necesidad de una educación autoritaria, moral y religiosa."

${ }^{67} \mathrm{O}$ manifesto titulábase "O Maxisterio diante da Autonomía de Galicia", e os dous primeiros asinantes eran Avelino Pousa Antelo e José Toba Fernández. Remataba con estas palabras: "Por ben de Galicia, por ben da escola, por ben do neno e pol-o noso propio ben: ¡A traballar pol-o éxito do plebiscito e pol-a redención da nosa terra!" (El Pueblo Gallego, 14 de xuño de 1936). 
A Comisión provincial non estimou necesario facer máis indagacións nin comprobacións. Considerou probada a súa participación destacada na Fronte Popular, o seu apoio ao "nefasto" Marcelino Domingo e o seu "sectarismo anticatólico", e asumiu a veracidade dos feitos relatados por Eiras Blanco, circunstancias todas elas comprendidas no apartado terceiro da circular de Comisión de Cultura e Ensino asinada por José María Pemán o 7 de decembro de $1936{ }^{68}$. En consecuencia, o 14 de xullo de 1937 propuxo que fose "confirmada" a sanción imposta no seu día a Xosé Toba pola extinguida Delegación Militar, e xa que logo definitivamente afastado do servizo, cos correspondentes efectos administrativos. Así se fixo, como xa sabemos, aínda que haberá que agardar case tres anos para coñecer a resolución ministerial.

O noso home demandará das autoridades a revisión do seu expediente de depuración. A primeira solicitude está datada o 22 de xaneiro de 1941, e ía acompañada dunha nova ampliación dos descargos e de dez certificados que acreditaban a súa boa conduta, asinados polos párrocos de Muxía, Sillobre -estes dous eran copia dos xa achegados-e Sar, a Garda Civil, a Falanxe e a Alcaldía ${ }^{69}$ coruñesas, dous militares, a superiora da Compañía de María e o superior dos Irmáns da Doutrina Cristiá de Santiago.

O mestre argumentaba que algúns destes informes non se limitaban a certificar a súa recta conduta, senón que o situaban "en la órbita de las ideas" que inspiraran o Movemento. Eugenio Pita Blanco, capitán de Infantaría, que estudara na Escola Normal de Santiago, testemuñaba, en efecto, o "completo desacuerdo con el ideal marxista" do imputado, mentres que Fernando Roldán Martínez, xuíz de primeira instancia e instrución e capitán honorario do corpo xurídico militar, con destino na Auditoría de Guerra de Xirona, daba fe da "afección" de quen dicía ser o seu amigo "con las esencias que inspiraron la formación del Nuevo Estado Español". Pola súa banda, os responsables dos dous colexios relixiosos manifestaban, en informes practicamente idénticos, non ter noticias de que Toba tentara clausuralos e que nunca molestara "en lo más mínimo" a ningunha das dúas comunidades relixiosas "en ninguno de sus aspectos". Aos dez informes mencionados uníase outro, datado o 29 de setembro do "ano da vitoria" e asinado polo coronel de Artillaría Ginés Montel Martínez, delegado de fabricación e xefe de Mobilización Industrial de Galicia, segundo o cal Toba, pertencente á quinta de 1925, traballara entre 010 de outubro de 1938 e o 30 de xuño de 1939 no taller militarizado "La Artística"-Suárez Pumariega S. A., "habiendo desempeñado su labor con gran celo e interés en la sección de fabricación de material de guerra, Granadas de Mano 'Lafitte', cooperando así al normal desenvolvimiento de la fabricación para el Glorioso Ejército Nacional."

Nos novos descargos non achega datos particularmente orixinais, senón que insiste na mesma liña argumental: a súa designación como concelleiro fora unha imposición gobernativa e tivera unha moi curta duración; algúns funcionarios que tamén formaran parte

\footnotetext{
68 "Separación definitiva del servicio para todos los que hayan militado en los partidos del 'Frente Popular' o sociedades secretas, muy especialmente con posterioridad a la revolución de Octubre, y de un modo general, los que perteneciendo o no a esas agrupaciones hayan simpatizado con ellas u orientado su enseñanza o actuación profesional en el mismo sentido disolvente que las informa" (BOP, 15/12/1936). A Comisión depuradora coruñesa apelará reiteradamente a este apartado nas propostas de resolución dos expedientes.

${ }^{69} \mathrm{O}$ alcalde afirmaba que residía na cidade da Coruña desde o mes de xuño de 1936, data en que traballaba e exercía como concelleiro en Compostela.
} 


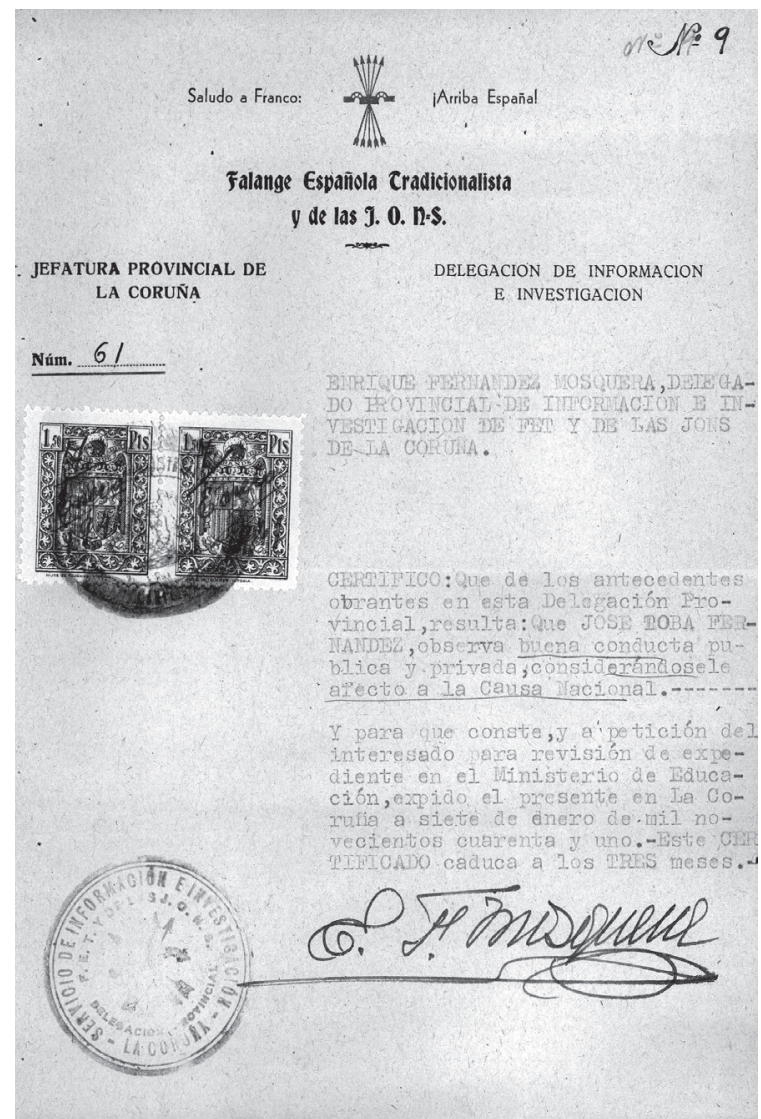

4. A Falanxe era unha das instancias fundamentais para emitir informes. Reproducimos o que tivo que mendigar Xosé Toba Fernández (AGA, 32/13337-27).

da xestora municipal compostelá e pertencían a outros ministerios foran sancionados unicamente con traslado dentro da provincia; non se interesara pola política, malia recoñecer o seu "amor a Galicia y simpatía en un regionalismo sano integrado en la unidad superior de España"; discrepara da actuación da Fronte Popular e da anarquía que provocara, incompatible cun home de orde como el era; e, en fin, algunhas das imputacións que se lle facían como docente só podían ter a súa orixe en persoas "de baja estirpe moral", que deberían ser conducidas aos tribunais no suposto de se coñecer a súa identidade.

O Xulgado Superior de Revisións, atendendo, entre outras consideracións, á gravidade dos cargos, algúns deles recoñecidos polo recorrente, e ao feito de que a maior parte dos novos informes non procedían de Santiago, o que evidenciaba a incapacidade de conseguilos nesa cidade debido aos seus antecedentes, acordou o 25 de maio de 1942 
desestimar o recurso, decisión que foi confirmada días despois pola dirección xeral correspondente. Mais o acordo non debeu ser comunicado ao interesado, pois o 15 de setembro de 1946 declaraba carecer de noticias ao respecto, segundo fai constar nunha instancia dirixida ao ministro de Educación para solicitar de novo a revisión do expediente en función das evidencias achegadas cinco anos antes.

No expediente consérvase unha folla con tres anotacións manuscritas sobre esta solicitude. Na primeira (26/9/1946) afírmase que, dada a gravidade dos cargos, non se podía proceder á reposición sen novos informes procedentes de Santiago que os atenuasen. $\mathrm{Na}$ segunda (25/10/1946) determinábase que a acusación máis grave, prescindindo da actuación política, radicaba en inculcar o marxismo aos escolares, como denunciara o mestre Eiras Blanco, extremo sobre o que procedía pedir informes ao director da Escola Normal compostelá. A terceira anotación (30/12/1946) concluía que o cargo de propaganda escolar marxista non fora confirmado, polo que se debía remitir o expediente á Comisión da Coruña para que, despois de practicar as dilixencias oportunas, incluída no seu caso a de solicitar novos informes a Santiago, informase a demanda de revisión.

José Crespo Rodríguez, director da Normal, dicía carecer de datos precisos, por máis que nunca detectara en Toba ideas revolucionarias nin marxistas, e dado que o denunciante xa morrera, quen mellor podía informar sobre o asunto eran José Benito Lamelo e Higinio Abeijón, mestres da graduada en 1935-1936, que continuaban en activo. O primeiro afirmaba que o director da graduada non propagara ideas revolucionarias entre os alumnos do seu grao nin lles ensinara o saúdo marxista, e sobre o "incidente" que houbera entre el e Eiras só sabía que estivera motivado "por el cambio de grado y el mal empleo del libro escolar". O segundo manifestaba practicamente o mesmo, aínda que era máis preciso sobre o "incidente" en cuestión, que tivera lugar na Xunta de Mestres, e non obedecera ás supostas ideas revolucionarias de Toba nin á práctica do saúdo marxista, senón a "sustentar ambos opiniones distintas respecto a la rotación de grados y al uso del libro escolar por los niños". No tocante aos libros, o director posiblemente cuestionara un uso que consideraba abusivo -no opúsculo xa citado celebraba a Rousseau como o "ariete implacable contra una Escuela irracional y libresca"-, fronte ao mestre da sección primeira, que probablemente lles concedía unha maior centralidade. Esta desavinza profesional seguramente motivou a delación posterior. De feito, o antigo rexente escribía na segunda ampliación dos descargos (22/1/1941) que algunhas acusacións ben podían obedecer a un "resentimiento por pequeñas diferencias inevitables en cualquier Claustro".

Tales eran as dilixencias que lle permitían ao redactor da nota manuscrita antes citada -é posible que se tratase do propio xuíz, Pío García Escudero- concluír que non se demostrara a existencia das leccións sobre como facer o saúdo marxista. Procedía, pois, enviar de novo o expediente á Coruña para que informase o delegado do Xulgado Superior na provincia, Jesús Babío Calleja. O seu texto, redactado o 15 de xullo de 1948, merece unha especial mención.

Comeza subliñando que as normas reguladoras da depuración do persoal do Ministerio de Educación Nacional tiveran nos seus inicios unha "rigidez" que estaba en 
sintonía coas "más puras esencias de todo lo que es y significa el Glorioso Alzamiento Nacional". El sabíao ben, pois fóranlle comunicadas en Burgos polas autoridades educativas da Xunta de Defensa, "directamente y en instrucciones verbales de carácter confidencial." E continúa:

Transmitidas que fueron a las Comisiones Depuradoras de esta Provincia aquellas instrucciones, por quien como el que informa venía del frente de batalla, se aplicaron a los casos prácticos, con la rigurosidad escrupulosa de que dan fe todos los expedientes tramitados en esta provincia.

Ahora bien, quiso el Legislador por su voluntad soberana e indiscutible, abrir un período de revisión para atemperar sin duda la labor realizada a las nuevas corrientes de incorporación de todos los españoles a la Causa Nacional.

De feito, prosegue o delegado, logo de revisar os expedientes á luz dos novos criterios, foron rehabilitadas persoas sobre as que recaeran acusacións máis graves que as formuladas contra Toba, "acusado únicamente de galleguismo separatista, imputación que actualmente resulta arcaica e inocente", e que segundo os testemuños que achegaba tiña unha boa conduta moral e profesional, "al menos en el orden externo". En consecuencia, proponse que se atenda a petición de rehabilitación do mestre compostelán.

Noutra nota manuscrita, que neste caso tiña como soporte a folla dun calendario de mesa, quedou constancia da conformidade coa proposta do delegado provincial, e engadíase que a reincorporación debería ir acompañada do traslado fóra das provincias galegas por tres anos, ademais da inhabilitación para cargos directivos e de confianza. Mais a conformidade foi riscada en espera dun informe confidencial pedido a Táboas -posiblemente se tratase de José Táboas Salvador, nomeado polos sublevados director da Escola Normal de Santiago e por esas datas inspector central das escolas de Maxisterio-, que se pronunciou en termos negativos, aínda que propuña solicitar a opinión da directora e do profesor de Relixión da Normal compostelá. Estes informes, conclúe a devandita nota, "inclinan a denegar la rehabilitación". Vexamos, a seguir, cal era o seu contido.

A directora, Pilar Martínez Álamo (10/11/1948), confirmaba que o mestre fora concelleiro galeguista, mais verbo da súa actuación docente nada podía informar, por non exercer ela a dirección nos tempos da República nin se conservaren datos no rexistro do centro. Algo máis sabía o profesor de Relixión e cóengo catedralicio, Andrés Lago Cizur (14/11/1948), malia non ser profesor da Normal na época de referencia, e mesmo parecía ter un certo afán por informar:

a) que el Sr. Toba Fernández perteneció a la Corporación municipal de esta ciudad integrada por miembros del llamado Frente Popular, representando en su seno al Partido de izquierda titulado GALLEGUISTA, desempeñando el cargo de tercer teniente alcalde; b) que, según testimonio recogido de labios del ex-alumno del Sr. Toba, y hoy sacerdote, D. Adolfo Mirelles ${ }^{70}$, el citado profesor de la Escuela Normal defendía en clase los postulados laicos de la República hasta el punto de haber expulsado de su aula a un discípulo que tuvo el valor cristiano de defender la enseñanza religiosa como necesaria, ordenándole que abandonara la clase con estas palabras: "no tolero que en esta clase se impugnen los principios básicos de la República".

${ }^{70}$ Este era precisamente o alumno ao que Toba propuña, nos seus primeiros descargos, que se lle preguntase sobre a súa actuación como docente na materia de Paidoloxía e Organización Escolar. 
A pesar do informe favorable de Jesús Babío, a intercesión de Buenaventura Castro Rial -nun caixón de escritorio de Pío García Escudero existía unha carta do director xeral de Previsión gabando a quen fora amigo seu desde a infancia-e as xestións realizadas por Nicolás Arias Andreu, xefe de Contabilidade e Orzamentos do Ministerio de Educación Nacional, a solicitude de readmisión foi denegada, segundo consta nun resumo mecanografado do expediente. Non se estimaba oportuno propiciar o retorno á escola dun "roxo" separatista -nótese a forma en que se refire o cóengo ao partido abandeirado por Castelao- e laico.

É por isto que houbo que reiniciar os trámites, facer novas xestións, pedir novos favores e mendigar novos informes -nunca se reparará dabondo na humillación e no calvario que supuxo este proceso para os depurados, mesmo para algúns dos que foron confirmados no cargo con todos os predicamentos-. O Xulgado, pola súa banda, pediu informes adicionais a diversas autoridades de Santiago. Un deles estaba asinado polo alcalde (11/6/1949), e nel podíase ler que Toba tivera, antes da sublevación, unha boa conduta, tanto dentro como fóra da escola. Ningunha alusión, pois, ao seu pasado como concelleiro da Fronte Popular, á que si aludía o comisario xefe da policía compostelá (16/5/1949), que o caracterizaba como "izquierdista y galleguista, demostrando en todos sus mítines su antiespañolismo".

Finalmente, despois de batallar durante trece anos, Xosé Toba conseguiu ser readmitido no maxisterio, atendendo as autoridades educativas, entre outras consideracións, á discrepancia dos informes remitidos desde Santiago. A readmisión ía acompañada dunha nova sanción: traslado fóra da provincia, prohibición de solicitar cargos vacantes durante dous anos e inhabilitación para o exercicio de cargos directivos e de confianza. A resolución foi asinada polo xuíz do Xulgado de Revisións e mais polo director xeral do ramo 02 de novembro de 1949.

Durante estes trece anos semella que se dedicou ao exercicio do ensino privado, como fixeron moitos outros sancionados ${ }^{71}$, e non sabemos se tamén a outras tarefas. Non abandonou estas actividades ata que o 11 de novembro de 1950 foi nomeado de forma provisoria mestre da escola graduada "Eusebio da Guarda" da Coruña.

Previamente tentara exercer as funcións de dirección, para as que estaba habilitado en virtude da oposición realizada no seu día. De feito, ao pouco de ser readmitido, a Comisión Permanente do Consello Provincial de Educación nomeouno, con carácter provisorio, di-

\footnotetext{
${ }^{71}$ Así se fai constar nunha carta que Julio Paradela dirixiu a Nicolás Arias Andreu (11/1/1949) para pedirlle consello sobre como proceder unha vez comprobado que, contrariamente ao que todos agardaban -o propio Pío García Escudero comunicáralle a Buenaventura Castro Rial que o seu informe sería favorable-, o expediente se ía resolver de novo en contra de Toba. "¿Será lo más conveniente ir en caliente a Madrid, y contando con su apoyo y de algún otro amigo, remover para que el Miinistro y el Director general oigan al interesado, o esperar otra coyuntura? El Sr. Toba está a disposición de una indicación suya. Yendo ahora no podría estar muchos días, pues tiene que suspender sus clases, mientras que en Semana Santa podría estar 15020 días. Y mientras tanto ¿no podría Vd. conseguir que se aplazase la publicación de esa Orden [de confirmación da sanción] en el B.O. del Ministerio? hasta que el interesado vaya a Madrid y pueda convencer a Don Pío, Don Romualdo o al Ministro de como es víctima de un enemigo."
} 
rector do grupo escolar "Ibáñez-Martín" de Ferrol, decisión que foi anulada pola Dirección Xeral de Ensino Primario, segundo a cal debía reincorporarse á profesión na súa condición de mestre, por estar inhabilitado para o exercicio de cargos directivos e de confianza. Toba, experimentado recorrente, non dubidou en presentar un recurso de alzada, argumentando que a dirección era un cargo técnico e profesional, polo que non estaba incluído na inhabilitación que sobre el recaera, cando menos se se facía unha "interpretación benévola" da lexislación. Mais ao entender das autoridades, a normativa depuradora aludía tanto aos cargos de confianza como aos directivos, e dentro destes últimos debían incluírse todos os que "supongan dirección, sin distinción alguna de modalidades de provisión ni de naturaleza". Ademais, o mestre fora sancionado con traslado fóra da provincia durante dous anos, e Ferrol compartía provincia con Santiago, polo que se desestimou o recurso mediante unha orde asinada precisamente polo ministro lbáñez-Martín. Tamén se desestimou o recurso de queixa motivado por non se resolver en prazo o de alzada ${ }^{72}$.

Ao se convocar 01 de febreiro de 1951 un concurso de traslados para a provisión de rexencias de escolas anexas ás de Maxisterio, Toba solicitou a de Lugo, que non lle foi concedida por estar pendente de cumprir a sanción de traslado por dous anos. Volveu reclamar mediante un recurso de reposición, alegando que a nota desfavorable do seu expediente fora cancelada, polo que se debía dar por cumprida a devandita sanción. 0 argumento tiña escaso peso: a cancelación fora anulada ao pouco de se ditar, precisamente "por no haber cumplido el interesado la sanción cuya nota desfavorable pidió que se le cancelase", segundo se pode ler na orde asinada por Ruiz-Giménez ${ }^{73}$.

Non se conformou Toba coa resolución e presentou un novo recurso, agora de agravios, co mesmo resultado que os anteriores. Na orde asinada por Carrero Blanco, que exercía a Presidencia do Goberno, reitéranse basicamente os anteriores argumentos: cando participara no concurso de traslados non cumprira os dous anos de permanencia fóra da provincia, as notas desfavorables só podían ser anuladas unha vez cumprida a sanción que as orixinara e carecía de relevancia a disquisición sobre se a dirección era un cargo técnico ou de confianza, por non ser esta a razón en que se fundamentaba a resolución ministerial recorrida ${ }^{74}$.

Como ben se pode apreciar, non lle faltaban folgos ao noso protagonista para defender os seus dereitos, por máis que a confrontación fose moi desigual e as conquistas que lles era dado conseguir aos vencidos fosen case sempre cativas, serodias e agridoces. En todo caso, algúns lograron unha importante vitoria: que o Terror non os paralizase.

Xosé Toba Fernández morreu 05 de setembro de 1963, cando só tiña 58 anos. Dous días máis tarde, a familia publicou unha esquela en La Voz de Galicia facendo saber que finara o director do grupo escolar "Concepción Arenal" da cidade coruñesa, e que por expresa disposición do finado non se comunicara o acto do sepellio. 09 de setembro, 0

\footnotetext{
${ }^{72}$ Ordes do 30 de xuño de 1950 en que se desestiman o recurso de alzada (BOE 11/7) e o de queixa (BOE, 16/7).

${ }^{73}$ Orde do 27 de outubro de 1951 (BOE, 4/11).

${ }^{74}$ Orde do 30 de xuño de 1952 (BOE, 5/10).
} 
mesmo xornal anunciaba a morte do armador do pesqueiro "Aguete" en esquela sufragada polos socios e amigos do armador e polo persoal e tripulación do pesqueiro.

\section{Palmira González López: "No obstante su sexo, lebantaba [sic], con frecuencia, el puño en alto"}

Vexamos agora a experiencia padecida por unha muller, Palmira González López irmá de Emilio, deputado de Izquierda Republicana-, que en xullo de 1936 rexentaba a escola de Arou-Camelle, situada no concello de Camariñas ${ }^{75}$.

Inicialmente foi suspendida de emprego e soldo por tres meses (BOP, 27/8/1936) ${ }^{76}$, e a finais de outubro, cando estaba a piques de cumprir a sanción, solicitou unha escola en réxime de interinidade. Asignóuselle a de Viñós, pertencente ao mesmo concello.

Por esas datas, a Comisión depuradora estaba recadando datos sobre a súa traxectoria. $O$ alcalde informou que, ademais de ter algo abandonada a escola, simpatizaba abertamente coa Fronte Popular, o que "tal vez" podería estar relacionado co feito de ser o seu irmán un dos candidatos desta coalición. Con todo, podería continuar exercendo 0 maxisterio, aínda que noutra localidade, "por tener vocación para la enseñanza y considerarla susceptible de rectificación de creencias políticas." A simpatía pola Fronte Popular transfórmase en propaganda no informe da Garda Civil, segundo a cal, "no obstante su sexo lebantaba [sic], con alguna frecuencia, el puño en alto", e era merecedora dunha sanción exemplar. O pai de familia declaraba que se trataba dunha "furibunda propagandista" do frontepopulismo, para o que pedira o voto nas pasadas eleccións, e que non atendía debidamente a escola.

Máis preciso e contundente era o párroco de Ponte do Porto. Na súa condición de mestra, Palmira era valorada negativamente en todos os apartados do cuestionario elaborado pola Comisión depuradora: unha calamidade, en suma. Porén, o que lle interesaba subliñar máis que nada era a súa irrelixiosidade: "Hacía labor antirreligiosa intensísima con sus palabras, pero sobre todo con su depravado ejemplo. Su fuerte es manifestarse atea". Así a cousas, "¿cómo puede formar corazones infantiles creyentes modelados en la fe de la verdadera España, quien tiene la desgracia inmensa de estar destituida de todo sentimiento religioso?". Polo demais, relacionábase con elementos de carácter subversivo, era frontepopulista, seguramente pertencía á Asociación de Traballadores do Ensino -tendo en conta a súa catadura- e no tocante á conduta particular, "faltando la religiosidad, no puede tener la dignidad propia de quien debe ser instructora y educadora de la niñez y ejemplo del pueblo."

\footnotetext{
${ }^{75}$ AGA, 32/12511-5.

${ }^{76}$ A concreción da duración será posterior.
} 


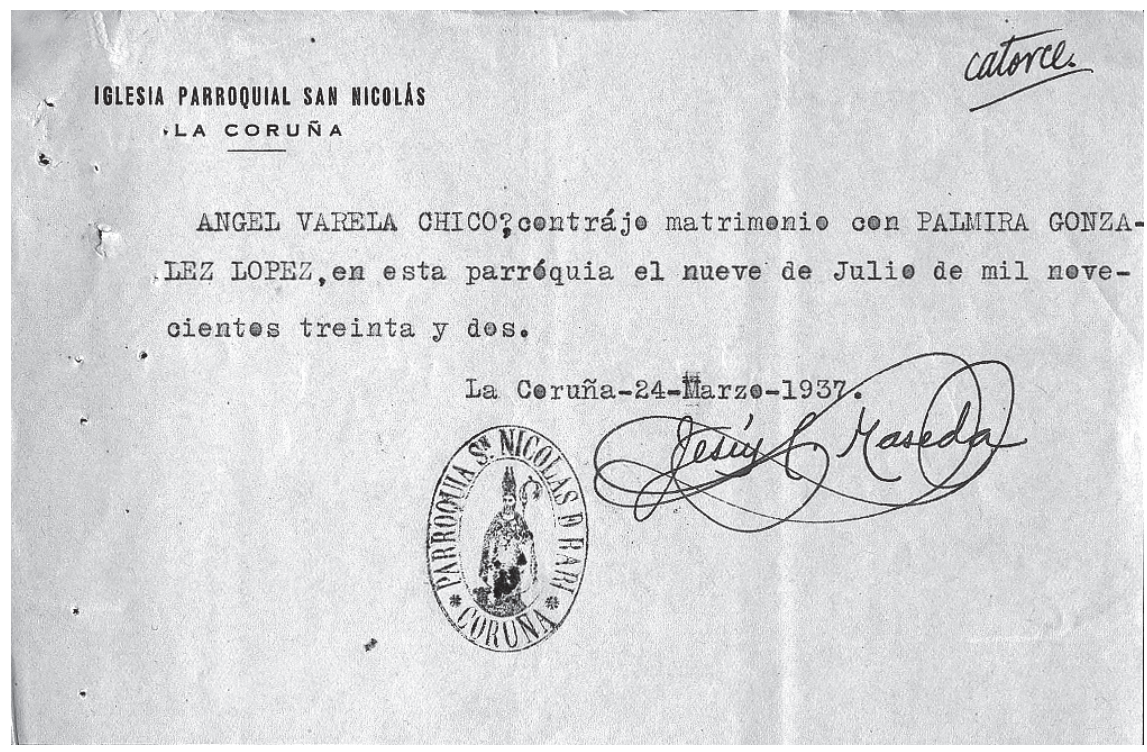

5. Fronte á acusación de ser una atea teórica e práctica, Palmira González López vese obrigada a presentar un certificado do seu matrmionio relixioso, celebrado en 1932, é dicir, en plena República. A Igrexa non daba feito tanto certificado como se lle requiría (AGA, 32/12511-5).

Ao ser nomeada para a escola de Viñós, o párroco do lugar, nada máis vela chegar, ventouna decontado: "me pareció del 'Frente Popular' y muy roja, por la clase de personas que le acompañaban". Así que se deu présa en solicitar antecedentes ao seu compañeiro de Ponte do Porto, o cal matiza e amplía o que xa sabemos. Para empezar, era "atea teórica y práctica", e así o evidenciaba a súa decisión de ausentarse de Arou cando se organizou unha misión, no canto de escoitar os sermóns durante os oito días que duraba, confesarse e despedir en manifestación o misioneiro, como fixeran os outros veciños. En febreiro, e coincidindo coas eleccións, estivera na cidade da Coruña, onde fixera "sinnúmero de embuchados en muchísimas mesas electorales", e retornara a Camariñas manifestando a súa ledicia pola vitoria "con los puños en alto" -ao parecer, non lle abondaba con erguer un-. En fin, na súa alma -diáfana para o párroco de Ponte do Porto- non aniñaba nin unha "pizca" de valor patriótico ou relixioso.

Quen dicía rebordar de patriotismo era o crego de Brandeso e do seu anexo Viñós, que remitiu o anterior informe ao presidente da Comisión depuradora animado por un "deber Patriótico" e acolléndose expresamente ás orientacións da circular da Comisión de Cultura e Ensino de 7 de decembro de 1936. Concluía a transcrición do texto do seu colega con estas palabras, de colleita propia: "Le suplico, por Dios, y por la Patria, resuelva inmediatamente este asunto, pues dicha Sra. sería aquí la corrupción de las conciencias de los niños." 
Atendendo á gravidade das imputacións que se lle facían, particularmente por parte do clero, a Comisión provincial solicitou á Comisión de Cultura e Ensino que se prolongase a suspensión de Palmira González López mentres non se resolvía definitivamente o expediente, como así se fixo en febreiro de $1937^{77}$. Tamén acordou dirixirse ao delegado de Orde Pública da provincia para que informase sobre a actuación da imputada nas eleccións de febreiro, e máis concretamente sobre se practicara "embuchados", é dicir, se introducira nas urnas papeletas de forma fraudulenta. A resposta recibida foi a seguinte:

\begin{abstract}
Dicha maestra abandonó su residencia en los días anteriores y posteriores a las elecciones del 16 de Febrero, realizando una activa campaña en pro del Frente Popular; el día de las elecciones fue por los Colegios Electorales animando al público y luego por la tarde se marchó a los pueblos cercanos a esta ciudad, levantando el puño y diciendo que la hora del triunfo había sonado. Esta campaña la hizo [a]compañada de su madre y hermana; estas dos últimas fueron las que cometieron las irregularidades electorales a que se refiere su mencionado oficio.
\end{abstract}

La Palmira está afiliada a la Federación de Trabajadores de la Enseñanza, afecta a la U.G.T., e identificada con los procedimientos de dicha organización.

Combatía las ideas religiosas y todas sus conversaciones eran una propaganda descarada de los ideales marxistas.

En función dos testemuños recibidos, e tamén do coñecemento que os membros da Comisión tiñan da encausada ${ }^{78}$, elaborouse o prego de cargos. Ascendían a sete: deixar de asistir de cando en vez á escola; ser atea e combater a relixión dentro e fóra da escola; exercer como propagandista da Fronte Popular na docencia e nas súas relación sociais; saudar co puño ergueito; pertencer á FETE; percorrer o 16 de febreiro os colexios electorais da capital e localidades máis próximas animando a xente a votar a candidatura frontepopulista; e propagar de forma descarada o ideario marxista. Estes sete cargos ben se poderían reducir a dous: ser atea e vermella.

Palmira negou todas e cada unha das acusacións, aínda que a súa pertenza á FETE, por exemplo, está corroborada polo seu irmán Emilio e confirmada polas listaxes de afiliados desta organización coas que se conseguiron facer os sublevados. Sexa como for, a mentira en defensa propia estaba, a meu entender, plenamente lexitimada pola ilexitimidade radical do proceso de depuración.

Na súa defensa achega, entre outros documentos, un certificado do seu matrimonio canónico, celebrado na igrexa de san Nicolás da cidade da Coruña o 9 de xuño de 1932,

\footnotetext{
${ }_{77}$ A Comisión apelaba ao artigo seis da Orde do 10 de novembro de 1936: "Cuando a juicio de la Comisión depuradora existan causas graves que lo aconsejen, podrán proponer a la Comisión de Cultura y Enseñanza la suspensión de empleo y sueldo del funcionario objeto del expediente, aunque este se halle en tramitación" (BOE, 11/11/1936).

${ }^{78}$ José Martínez Pereiro, o relator encargado de fundamentar a solicitude de que se decretase a suspensión mentres non se resolvía o expediente, dicía que algúns informes se limitaban a corroborar o que el oíra en repetidas ocasións. Parece, pois, que os xuíces non se privaban de exercer tamén o papel de fiscais, e dispuñan dunha marxe de actuación moi ampla. A circular da Comisión de Cultura e Ensino do 28 de xaneiro de 1937 establecía que "las Comisiones y cada uno de sus Vocales podrán proponer sanción siempre que en conciencia crean acreedor a ella al encartado, aun en los casos en que por circunstancias especiales no haya en el expediente prueba bastante por escrito" (BOP, 6/2/1937).
} 
e alude a diversas persoas que poderían testemuñar "que no soy tan mala persona como quieren hacer ver algunos de los informantes". Declara ser vítima dunha vinganza caciquil, organizada, entre outros, polos médicos do concello, adversarios políticos do seu irmán Emilio -un deles, Tomás Arteaga, declarou efectivamente en calidade de pai de familia-. Tamén consegue que 13 veciñas e 8 veciños asinen un escrito, datado o 14 de marzo de 1937, en que manifestan a súa satisfacción pola actuación da mestra, que

\begin{abstract}
atendió siempre con gran solicitud y cariño a nuestros hijos, en los que observamos grandes adelantos, no les enseñó malas adoctrinas, antes bien les aconsejaba el respeto a sus padres y vecinos de la aldea y en las conversaciones que con el público sostenía jamás hizo manifestaciones políticas ni antirreligiosas, ni tampoco hemos visto que saludase a la gente con el puño cerrado, sino por el contrario, siempre saludaba como saludan las personas bien educadas, de palabra y con consideración y afecto. Afirmamos que el día anterior a las elecciones dio la clase como de ordinario y salió en automóvil particular con su hermano después de la clase de la tarde, ya casi de noche, y al día siguiente la vimos llegar en el automóvil de Guillén.
\end{abstract}

Seis días máis tarde de se redactar este escrito, alguén fixo circular outro que sostiña 0 contrario: Palmira González López exercera presión sobre a xente para que votase as candidaturas da Fronte Popular e saudaba co puño ergueito, ao tempo que daba vivas a Largo Caballero, Casares Quiroga e Manuel Azaña; censurara a unha das asinantes por darlle pousada ao misioneiro que xa coñecemos; non pisaba a igrexa e, en fin, faltaba con frecuencia á escola. Son moitas as persoas que avalan o texto, aínda que as máis delas non asinan -supoñemos que por non o saberen facer-, senón que o fan outras ao seu rogo. Segundo as miñas contas, os rogos suman 72 para un total de 106 adhesións: 17 de 41 no caso dos homes e 55 de 65 no das mulleres. Estas cifras poderían traducirse nunha taxa de alfabetización masculina de aproximadamente $058 \%$, que se pode considerar máis ou menos representativa da existente no concello de Camariñas por esas datas, tomando en consideración os valores rexistrados en 1930 e 1940, e nunha taxa feminina do 15\%, que en absoluto sería representativa, por ser unhas tres veces inferior á media que podemos estimar para 1937. Semella, pois, que se fixo unha selección claramente nesgada, cando menos desde a perspectiva literaria, da ampla mostra de asinantes femininas, o que suscita certas dúbidas sobre a limpeza e fiabilidade do documento.

Algúns dos 106 asinantes declaraban que tamén avalaran o documento anterior, favorable a dona Palmira. Explicaban esta contradición alegando que "hemos sido sorprendidos por dicha profesora, firmándole en blanco un papel, que llorando, nos rogó hiciéramos para impedir que la matasen." Supoñemos que por "sorprender" querían significar que non tiveran tempo de reflexionar sobre se debían asinar, mais o feito de o faceren, e ademais en branco, constitúe a mellor proba da súa confianza na mestra, cuxos temores de ser asasinada estaban máis que fundamentados.

O seu irmán Antonio fora "paseado" despois dunha desas "sacas" que tanto proliferaron no verán de 1936, e o seu corpo abandonado nun camiño de Dorneda (Oleiros) durante toda a noite, ata que, ben entrada a mañá, se puideron facer cargo dos restos mortais a nai e mais Palmira. O irmán máis novo, Fernando, que pertencía ás Xuventudes Socialistas Unificadas, foi preso e ingresado na praza de touros da Coruña, onde a piques estivo de ser asasinado por un grupo de falanxistas cando o estaban introducindo nun camión: "Al 
subir mi hermano por la rampa y acercársele el sacerdote con su crucifijo, mi hermano, sin duda enloquecido, le dio un golpe al crucifijo y probablemente otro al sacerdote." Os falanxistas comezaron a mallar nel, "para anticipar su asesinato matándolo en la misma plaza"; salvoulle a vida un capitán da Garda Civil, Rodrigo Santos Otero, que o identificou como irmán de Emilio, de quen era íntimo amigo. Outro irmán, Enrique, empregado en Obras do Porto da Coruña, sufriu unha sanción administrativa, e o pai, o maltrato dos falanxistas, que mesmo tentaron acabar coa súa vida, e posteriormente o cárcere ${ }^{79}$. A propia mestra, segundo nos conta o seu sobriño, Ángel del Castillo González, estaba ameazada de morte, polo que se viu obrigada a agocharse ${ }^{80}$. Como para non ter medo...

A Comisión depuradora, na sesión que tivo lugar o 10 de maio de 1937, considerou probados os cargos, e acordou propoñer que a sanción de suspensión de emprego e soldo imposta pola desaparecida Delegación Militar fose elevada a destitución, polo que a mestra debía ser definitivamente separada do servizo, cos conseguintes efectos administrativos. A Comisión de Cultura e Ensino aceptará a proposta, e fará pública a súa decisión no BOE do 7 de agosto de 1937.

A nosa mestra solicitou a revisión do expediente o 8 de marzo de 1941, apelando á GRAZA, mais tamén á XUSTIZA, con maiúsculas as dúas. Entendía que se a case todos os españois lles correspondía unha certa cota de responsabilidade no "estado de descomposición a que había llegado nuestra querida Patria", a súa estaba cumpridamente paga. Non foron dese parecer as autoridades superiores, para as que a recorrente non achegaba probas que permitisen rebater os gravísimos cargos que se lle apuñan. Tentou sorte de novo en 1944, e o recurso semella que se ía resolver no mesmo sentido, segundo se desprende dunha nota manuscrita, malia o moi favorable informe do xa mencionado capitán da Garda Civil, agora xubilado e que tivera baixo a súa xurisdición entre 1932 e 1939 o concello onde exercera a mestra. O criterio seguramente mudou a raíz dunha carta enviada por Nicolás Arias, a quen xa coñecemos, ao xuíz revisor, Pío García Escudero, na que lle solicitaba que se interesase por este expediente.

A recomendación resultou efectiva, e en novembro de 1945 o xuíz propuxo a modificación da sanción: suspensión de emprego e soldo durante dous anos, período para 0 cal computaba o tempo xa transcorrido -ascendía a máis de nove anos-, traslado fóra da provincia, prohibición de solicitar vacantes durante cinco anos e inhabilitación para o desempeño de cargos directivos e de confianza. $O$ director xeral aceptou a proposta e dona Palmira puido reincorporarse á escola. Ángel del Castillo González conta que tivo dous destinos: Arbo primeiro e logo Malpica.

\footnotetext{
${ }^{79}$ Emilio González López, Memorias de un diputado republicano en la guerra civil española (1936-1939) (Sada: Ediciós do Castro, 1990), 3-14, 44-46 e 239-240.

${ }^{80}$ Alguén a avisou de que andaban á súa procura, "y doña Palmira corrió y recorrió campos a traviesa, cruzando maizales para esconderse y pasar desapercibida" (Ángel del Castillo González, Mis recuerdos, https://www. wattpad.com/572424-mis-recuerdos)
} 


\section{Consideracións finais}

O fascismo español quería axustar contas co pasado máis inmediato, que cristalizara na vitoria da Fronte Popular nas eleccións de febreiro de 1936, á que contribuíu un sector do maxisterio, partidario da República e do Progreso. O nacional-catolicismo tamén precisaba dotarse dun novo modelo de mestre, que permitise o retorno á "España eterna", e que estaba nas antípodas da figura do "mestre republicano". Unha e outra circunstancia -ese afán punitivo e asemade preventivo que, en palabras de José María Pemán, animaba os sublevados- determinaron unha brutal represión do maxisterio, que quedou privado dalgúns dos seus mellores efectivos, tamén na provincia da Coruña. Deste proceso de depuración, practicado sen piedade, resultou un maxisterio humillado, empequenecido e empobrecido. E sometido, de novo, ao imperio do clero, que foi o gran gañador da "guerra escolar". 